medRxiv preprint doi: https://doi.org/10.1101/2021.04.23.21255957; this version posted April 26, 2021. The copyright holder for this preprint

(which was not certified by peer review) is the author/funder, who has granted medRxiv a license to display the preprint in perpetuity.

This article is a US Government work. It is not subject to copyright under 17 USC 105 and is also made available for use under a CCO license.

\title{
Effect of biannual azithromycin distribution on antibody responses to malaria, bacterial, and protozoan pathogens among children: A cluster-randomized, placebo-controlled trial in Niger
}

Ahmed M. Arzika, ${ }^{1}$ Ramatou Maliki, ${ }^{1}$ E. Brook Goodhew, ${ }^{2}$ Eric Rogier, ${ }^{2}$ Jeffrey W. Priest, ${ }^{3}$ Elodie Lebas, ${ }^{4}$ Kieran S. O'Brien, ${ }^{4}$ Victoria Le ${ }^{4}$ Catherine E. Oldenburg, ${ }^{4,5,6}$ Thuy Doan, ${ }^{4,5}$ Travis C. Porco, ${ }^{4,5,6}$ Jeremy D. Keenan, ${ }^{4,5}$ Thomas M. Lietman, ${ }^{4,5,6}$ Diana L. Martin, ${ }^{2}$ Benjamin F. Arnold, ${ }^{4,5}{ }^{*}$ for the MORDOR-Niger Study Group ${ }^{\dagger}$

1. The Carter Center Niger, Niamey, Niger

2. Division of Parasitic Diseases and Malaria, Centers for Disease Control and Prevention, Atlanta, GA, USA.

3. Division of Foodborne, Waterborne and Environmental Diseases, Centers for Disease Control and Prevention, Atlanta, GA, USA.

4. Francis I. Proctor Foundation, University of California, San Francisco, CA, USA.

5. Department of Ophthalmology, University of California, San Francisco, CA, USA.

6. Department of Epidemiology and Biostatistics, University of California, San Francisco, CA, USA.

* Corresponding Author:

Benjamin F. Arnold, PhD

Assistant Professor

Francis I. Proctor Foundation

University of California, San Francisco

$+1-415-514-3227$

ben.arnold@ucsf.edu

$\dagger$ listed at the end of this article

\section{Abstract}

Background: The Macrolides Oraux pour Réduire les Décès avec un Oeil sur la Résistance (MORDOR) trial in Niger, Malawi, and Tanzania found that biannual mass distribution of azithromycin to children younger than 5 years led to a $13.5 \%$ reduction in all-cause mortality. Additional endpoints in the trial have attempted to elucidate the mechanisms for mortality reduction. In this pre-specified secondary analysis, we assessed the effect of azithromycin compared with placebo on IgGbased measures of infectious disease exposure with a multiplex bead assay that included antigens to malaria parasites (Plasmodium falciparum, P. vivax, P. malariae, P. ovale), bacterial pathogens (Campylobacter spp., enterotoxigenic Escherichia coli, Vibrio cholerae, Salmonella enterica, Streptococcus pyogenes) and protozoans (Cryptosporidium parvum, Giardia duodenales). Methods and Findings: Thirty communities in rural Niger were randomized 1:1 to biannual distributions of azithromycin or placebo among children ages 1-59 months. The analysis included 5,642 blood specimens collected from 3,814 children ages 1-59 months, measured at 6, 12, 24, and 36 months of follow-up in a repeated crosssectional design. Campylobacter spp. seroprevalence averaged over all study visits was lower in azithromycin communities compared to placebo ( $91 \%$ vs $94 \%$, difference $=-3 \%, 95 \% \mathrm{Cl}:-5 \%,-1 \% ; P=0.03$ ), which corresponded to a $29 \%$ lower seroconversion rate (1.30 versus 1.84 seroconversions per year, hazard ratio $=0.71,95 \% \mathrm{Cl}: 0.56,0.89 ; P=0.004)$. Antibody-based measures of infection with $P$. falciparum and group A streptococcus were consistently lower in azithromycin communities, but were not statistically different from placebo, and there were no other differences across pathogens. Strengths of the study included masking of participants, investigators, and analysts, high treatment coverage, large sample size, and objective outcomes. Principal limitations included the timing of blood collection with respect to treatment (approximately 6 months later, which could have missed transient effects in the weeks immediately following treatment), and the durability of IgG response following clearance of infection. Both limitations would lead the trial to under-estimate effects on antibody-based measures of infection. Conclusions: The reduction in Campylobacter spp. despite these limitations suggests an effect on carriage, findings which align with an independent metagenomic analysis of rectal swabs collected in the same villages and with previously reported reductions in dysentery-associated mortality. Given significant sequelae of Campylobacter infection among preschool aged children, our results support at least one possible mechanism through which biannual mass distribution of azithromycin likely reduced mortality in this study population. 
medRxiv preprint doi: https://doi.org/10.1101/2021.04.23.21255957; this version posted April 26, 2021. The copyright holder for this preprint

(which was not certified by peer review) is the author/funder, who has granted medRxiv a license to display the preprint in perpetuity.

This article is a US Government work. It is not subject to copyright under 17 USC 105 and is also made available for use under a CCO license.

\section{Introduction}

Child mortality rates in Niger are among the highest in Africa [1]. We previously conducted a clusterrandomized, placebo-controlled trial in Niger, Malawi, and Tanzania to assess the effect of biannual mass distribution of azithromycin on mortality among preschool aged children (MORDOR) [2]. In Niger, azithromycin reduced all-cause mortality by $18 \%$, spurring interest in identifying specific mechanisms of pathogen reduction through which azithromycin reduced mortality. Follow-up analyses of MORDOR Niger demonstrated reductions in cause-specific mortality that spanned many leading causes of death in the region (e.g., malaria, pneumonia, diarrhea), suggesting effects were unlikely to result from a single mechanism [3]. An intensive monitoring trial in MORDOR Niger also documented lower levels of malaria parasitemia [4] and reduced Campylobacter upsaliensis carriage [5]. Studies that further clarify the mechanisms of mortality reduction from azithromycin could help identify complementary interventions or identify alternative interventions that lead to similar benefits but have lower potential to select for antimicrobial resistance [6].

In this pre-specified, secondary analysis of the MORDOR Niger trial, our objectives were to assess the effect biannual mass distribution of azithromycin to preschool aged children on serological measures of malaria, bacterial, and protozoan infections. Using a multiplex bead assay, we measured IgG responses to malaria parasites (Plasmodium falciparum, $P$. vivax, $P$. malariae, $P$. ovale), Campylobacter spp., enterotoxigenic Escherichia coli (ETEC), Vibrio cholerae, non-typhoidal Salmonella (serogroups B and D), Streptococcus pyogenes (serogroup A), Cryptosporidium parvum, and Giardia duodenalis. We hypothesized that, compared to placebo, children who received azithromycin would have lower levels of infection and thus lower IgG responses to the pathogens measured. Our rationale was based on evidence that azithromycin has antimicrobial activity against $P$. falciparum, P. vivax, group A Streptococcus, and gram negative bacteria including Campylobacter, 
medRxiv preprint doi: https://doi.org/10.1101/2021.04.23.21255957; this version posted April 26, 2021. The copyright holder for this preprint

(which was not certified by peer review) is the author/funder, who has granted medRxiv a license to display the preprint in perpetuity.

This article is a US Government work. It is not subject to copyright under 17 USC 105 and is also made available for use under a CCO license.

ETEC, cholera, and Salmonella [7-14]. Although not a first line treatment, azithromycin has antimicrobial activity against enteric protozoans Cryptosporidium [15] and Giardia [16,17].

\section{Materials and Methods}

\section{Ethics Statement}

The trial protocol was reviewed and approved by the Committee on Human Research at the University of California, San Francisco, and the Niger Ministry of Health's Ethical Committee. Parents or guardians of enrolled children provided oral consent before each azithromycin or placebo treatment and at each specimen collection visit. Parents or guardians were instructed to report any adverse event within 7 days of treatment by contacting their village representative, who then reported events to the site coordinator and UCSF. An independent Data and Safety Monitoring Committee provided additional oversight. CDC researchers had access to de-identified samples for analysis (no personally identifying information).

\section{Study design and participants}

MORDOR Niger was a cluster-randomized, placebo-controlled trial that randomized at the community level because of the intervention's campaign-style, biannual mass distribution. Communities with 200 to 2,000 inhabitants based on the Niger 2012 census were eligible for inclusion in the trial, and children ages 1-59 months who weighed $>3.8 \mathrm{~kg}$ were eligible for treatment. An intensive morbidity monitoring trial enrolled 30 communities and randomized them 1:1 to receive either biannual azithromycin or placebo to all children 1-59 months old (CT02048007). The trial used a repeated cross-sectional design, whereby 40 children per community were randomly sampled in each measurement round and invited to participate in a monitoring visit. The trial's open cohort design meant 
medRxiv preprint doi: https://doi.org/10.1101/2021.04.23.21255957; this version posted April 26, 2021. The copyright holder for this preprint

(which was not certified by peer review) is the author/funder, who has granted medRxiv a license to display the preprint in perpetuity.

This article is a US Government work. It is not subject to copyright under 17 USC 105 and is also made available for use under a CCO license.

that children aged in and out of the study based on their age at the time of treatment. Field staff collected dried blood spots from participating children at baseline and annually thereafter at 12,24 , and 36 months of follow-up. The antibody substudy included a supplemental visit at 6 months, following the malaria season. Children who were randomly selected in multiple survey rounds contributed to longitudinal analyses.

\section{Randomization and Masking}

Communities were randomized 1:1 using a sequence the trial biostatistician (TCP) generated. Unmasked members of the data team and Pfizer labeled the study drugs. Placebo and azithromycin had identical packaging to maintain masking. Participants, field staff, laboratory staff, analysts, and all investigators were masked to treatment assignments throughout the trial. Masked analyses were completed using a shuffled version of the treatment assignment variable [18]. Data were unmasked only after the final table and figure shells had been populated (documented through the article's GitHub repository).

\section{Procedures}

Children ages 1-59 months received azithromycin or identically-appearing placebo at the time of enrollment and every 6 months over the course of the study through community-wide census and MDA distributions performed by study staff. Children were given a volume of oral suspension equal to at least $20 \mathrm{mg}$ per kilogram of body weight, which was measured by hanging scale for children unable to stand or by height stick for children who could stand, consistent with the Niger trachoma program. Children with known allergy to macrolides did not receive azithromycin or placebo. 
medRxiv preprint doi: https://doi.org/10.1101/2021.04.23.21255957; this version posted April 26, 2021. The copyright holder for this preprint

(which was not certified by peer review) is the author/funder, who has granted medRxiv a license to display the preprint in perpetuity.

This article is a US Government work. It is not subject to copyright under 17 USC 105 and is also made available for use under a CCO license.

\section{Antibody testing}

Sample collection and preparation

Dried fingerprick blood spots (DBS) were collected onto calibrated filter paper wheels with $610 \mu \mathrm{l}$ extensions (TropBio Pty Ltd., Townsville, Queensland, Australia) and prepared as previously described [19]. Extensions were eluted overnight at $4^{\circ} \mathrm{C}$ in PBS containing $0.5 \%$ casein, $0.3 \%$ Tween-20, $0.5 \%$ polyvinyl alcohol, $0.8 \%$ polyvinylpyrrolidone, $0.02 \%$ sodium azide, and $3 \mu \mathrm{g} / \mathrm{mL}$ E. coli extract (Buffer B). Elutes were diluted to a final concentration of 1:400 with additional Buffer $B$ to test on the multiplex bead assay.

\section{Antigen coupling}

Antigens were coupled to polystyrene beads (SeroMap Beads; Luminex Corporation, Austin, TX) through chemical modification as previously described [19]. Malaria antigens MSP-1, AMA1, Glurp-R0, LSA1, CSP, and HRP2 were coupled for the detection of Plasmodium falciparum. Species specific MSP-1 was used to detect P. vivax, P. malariae, P. ovale [20]. Bacterial and protozoan antigens from Campylobacter jejuni (p18, p39), enterotoxigenic Escherichia coli labile toxin B subunit (ETEC LTB), Vibrio cholerae toxin B subunit (CTB), Salmonella serogroups B and D (LPS), Cryptosporidium parvum (Cp17, Cp23), Giardia duodenalis (VSP-3, VSP-5), and Streptococcus pyogenes serogroup A Pyrogenic Exotoxin B (SPEB) were also coupled to beads using previously described methods $[21,22]$.

\section{Multiplex bead assay}

We measured IgG responses using a multiplex bead assay on the Luminex platform. Antigencoupled beads (1250 per well/bead coupling) were incubated in 96-well assay plates with diluted sample for 1.5 hours then washed with $0.3 \%$ Tween-20 in PBS (PBST). Beads were washed with PBST 
medRxiv preprint doi: https://doi.org/10.1101/2021.04.23.21255957; this version posted April 26, 2021. The copyright holder for this preprint

(which was not certified by peer review) is the author/funder, who has granted medRxiv a license to display the preprint in perpetuity.

This article is a US Government work. It is not subject to copyright under 17 USC 105 and is also made available for use under a CCO license.

and incubated with biotinylated mouse anti-human $\lg G$ and biotinylated mouse anti-human lgG4 for 45 minutes to detect antigen IgG bound to the beads. After additional washes with PBST, beads were incubated for 30 minutes phycoerythrin-labeled streptavidin to detect bound biotinylated anti-human IgG. After detection, beads were washed with PBST and incubated for 30 minutes with PBS containing $0.5 \%$ BSA, $0.05 \%$ Tween- 20 and $0.02 \%$ sodium azide to remove loosely bound antibodies. After a final wash with PBST, beads were resuspended in PBS and stored at $4^{\circ} \mathrm{C}$ overnight. The next day, assay plates were read on a Bio-Plex 200 instrument (Bio-Rad, Hercules, CA) equipped with Bio-Plex manager 6.0 software (Bio-Rad). The median fluorescence intensity (MFI) with the background from the blank well (Buffer B alone) subtracted out (MFI-bg) was recorded for each antigen for each sample.

\section{Outcomes}

We compared groups using geometric mean $\lg G$ responses, seroprevalence, and the seroconversion rate, including measurements at all follow-up times (6, 12, 24, 36 months). These were pre-specified, secondary outcomes for the trial (NCT02048007).

\section{Statistical analysis}

\section{Seropositivity cutoffs}

We $\log _{10}$ transformed Luminex MFI-bg IgG levels before analysis. We converted IgG responses to seropositive and seronegative classes using seropositivity cutoffs derived from the mean plus 3 standard deviations (SD) of responses from a panel of known seronegative sera (malaria antigens), from ROC-derived cutoffs based on responses from known positive and negative specimens (Cryptosporidium, Giardia), or from the mean plus $3 \mathrm{SD}$ of presumed unexposed measurements (all other antigens). We identified presumed unexposed measurements as those collected among children 
medRxiv preprint doi: https://doi.org/10.1101/2021.04.23.21255957; this version posted April 26, 2021. The copyright holder for this preprint

(which was not certified by peer review) is the author/funder, who has granted medRxiv a license to display the preprint in perpetuity.

This article is a US Government work. It is not subject to copyright under 17 USC 105 and is also made available for use under a CCO license.

$\leq 12$ months old that preceded a 10 -fold increase in $\operatorname{lgG}$ in the longitudinal subsample [21]. For pathogens with multiple antigens measured, we classified children as seropositive if they were positive to any antigen. For $P$. falciparum, we examined individual antibody endpoints as well as a composite outcome, defined as a seropositive response to any $P$. falciparum antigen measured.

\section{Age restrictions}

We restricted age ranges included in the analyses based on pre-specified rules to exclude maternal IgG contributions and to focus the analysis on age ranges with heterogeneity in IgG responses. Before data were unmasked, we examined age-antibody profiles for each antigen and excluded from the primary analyses measurements among children $<12$ months (malaria responses) and $<6$ months (bacterial and protozoan responses) to remove potential maternally-derived IgG contributions (SI Figure 1, SI Figure 2) [23]. Additionally, we limited all analyses of ETEC LTB to ages 6-24 months and force of infection analyses based on seroconversion rates to measurements among children $\leq 24$ months (all enterics except Salmonella sp.) because nearly all children older than 24 months were seropositive.

\section{Estimation of mean differences}

All comparisons were intention-to-treat. We compared mean differences between groups in geometric mean $\operatorname{lgG}$ levels and seroprevalence by pooling all post-treatment measurements. We estimated $95 \%$ confidence intervals using a non-parametric bootstrap that resampled communities with replacement (1000 iterations). We calculated exact permutation $P$-values from the randomization distribution of mean differences. 
medRxiv preprint doi: https://doi.org/10.1101/2021.04.23.21255957; this version posted April 26, 2021. The copyright holder for this preprint

(which was not certified by peer review) is the author/funder, who has granted medRxiv a license to display the preprint in perpetuity.

This article is a US Government work. It is not subject to copyright under 17 USC 105 and is also made available for use under a CCO license.

Age structured seroprevalence and force of infection

We used a current status, semi-parametric proportional hazards model to estimate force of infection from age-structured seroprevalence [24]. We fit a generalized additive mixed model with binomial errors and complementary log-log link:

$$
\log \left(-\log \left[1-P\left(Y_{i j}=1 \mid A_{i j}, X_{i}, b_{i}\right)\right]\right)=g\left(A_{i j}\right)+\beta_{1} X+b_{i}
$$

where $Y_{i j}$ is antibody seropositivity, $A_{i j}$ is age for child $j$ in community $i . X_{i}$ is treatment allocation for community $i$ (equal to 1 for azithromycin, 0 for placebo). The model included community-level random effects, $b_{i}$, to allow for correlated outcomes within community. Function $g(\cdot)$ was parameterized with cubic splines that had smoothing parameters chosen through generalized cross-validation using the default in the $\mathrm{R}$ mgcv package [24]. The primary analysis pooled information over all postrandomization measurements available at the time of analysis (months $6,12,24,36$ ). We estimated the hazard ratio $(\mathrm{HR})$ of seroconversion associated with biannual mass distribution of azithromycin as $\hat{\theta}_{H R}=\exp \left(\hat{\beta}_{1}\right)$.

We estimated age- and treatment-specific seroprevalence from the model as:

$$
\widehat{P}(Y=1 \mid A=a, X=x)=1-\exp (-\exp [\hat{\eta}(a, x)])
$$

and we estimated age- and treatment-specific force of infection from the model as:

$$
\hat{\lambda}(a)=\eta^{\prime}(a, x) \exp [\hat{\eta}(a, x)]
$$

where $\eta^{\prime}(a, x)$ is the first derivative of the linear predictor from the complementary log-log model, $\eta(a, x)$ [25]. We estimated $\eta^{\prime}(a, x)$ using finite differences from the model predictions $[24,26]$. We estimated approximate, simultaneous 95\% confidence intervals around age-specific seroprevalence and age-specific force of infection curves with a parametric bootstrap (10,000 replicates) from posterior estimates of the model parameter covariance matrix [27]. We used age-specific force of infection curves 
medRxiv preprint doi: https://doi.org/10.1101/2021.04.23.21255957; this version posted April 26, 2021. The copyright holder for this preprint

(which was not certified by peer review) is the author/funder, who has granted medRxiv a license to display the preprint in perpetuity.

This article is a US Government work. It is not subject to copyright under 17 USC 105 and is also made available for use under a CCO license.

to visually confirm proportional hazards between groups. To estimate the marginal average force of infection in each group, we integrated over age [28].

\section{Longitudinal rate estimates}

A subset of children was sampled in multiple, repeated cross-sectional surveys and thus provided longitudinal antibody measurements (two to five visits). We conducted a supplemental analysis in this opportunistic subgroup to estimate prospective seroconversion and seroreversion rates. We defined seroconversion as an increase in IgG MFI-bg to a level above the antibody's seropositivity cutoff. For pathogens with multiple measured antigens, a child was deemed to have seroconverted if either antibody response met the definition for seroconversion. We assumed that seroconversions occurred at the midpoint of the interval between measurements when estimating person-time at risk. We jointly estimated seroreversion rates using the same approach, using decrease in $\lg G$ across the seropositivity cutoff. We used a non-parametric bootstrap, resampling clusters with replacement, to estimate $95 \%$ confidence intervals for rate and incidence rate ratio estimates.

\section{Subgroup analyses}

We pre-specified examining treatment differences by age at the trial's start date $(<6$ months vs older) and by trial phase $(6,12,24,36)$. We hypothesized that azithromycin could reduce antibodybased measures of transmission more among younger children who were immunologically naïve, and at later phases of the trial due to additional rounds of biannual MDA. We omitted a pre-specified subgroup analysis for rainy versus dry season because we ultimately determined that too few samples were collected after the rainy season (6-month samples only). 
medRxiv preprint doi: https://doi.org/10.1101/2021.04.23.21255957; this version posted April 26, 2021. The copyright holder for this preprint

(which was not certified by peer review) is the author/funder, who has granted medRxiv a license to display the preprint in perpetuity.

This article is a US Government work. It is not subject to copyright under 17 USC 105 and is also made available for use under a CCO license.

Statistical power, detectable effects, and adjustment for multiple comparisons

The MORDOR morbidity monitoring trial was designed around the primary antimicrobial resistance monitoring endpoints [5,29]. For the present analyses, assuming a sample of 15 communities per arm and 140 measurements per community over four rounds, seroprevalence of $65 \%$ ( $P$. falciparum), a community-level ICC of 0.004 , and a two-sided alpha of $5 \%$, we estimated that we would have $80 \%$ power to detect a reduction of 5.4 percentage points in seroprevalence due to intervention [30] (the pre-analysis plan provides additional details, https://osf.io/d9s4t) $)$. Within each set of analyses, we estimated $P$-values adjusted for multiple comparisons allowing for a $5 \%$ false discovery rate using the Benjamini-Hochberg correction [31].

\section{Data and materials availability}

Data and computational notebooks used to conduct the analyses are available through the Open Science Framework (https://osf.io/954bt) and Dryad (xx DOI forthcoming xx). Analyses used R statistical software, version 4.0.2.

\section{Results}

\section{Study population and setting}

The antibody substudy enrolled 3,814 children aged 1-59 months and tested a total of 5,642 blood specimens through the 36-month follow-up between March 2015 and June 2018 (Figure 1). One community withdrew from the trial at 36 months due to internal politics and trial fatigue. Except for the 6-month measurement, which took place after the seasonal rains, all other specimens were collected March - July toward the end of the dry season (SI Figure 3). Treatment coverage was high throughout 
medRxiv preprint doi: https://doi.org/10.1101/2021.04.23.21255957; this version posted April 26, 2021. The copyright holder for this preprint

(which was not certified by peer review) is the author/funder, who has granted medRxiv a license to display the preprint in perpetuity.

This article is a US Government work. It is not subject to copyright under 17 USC 105 and is also made available for use under a CCO license.

the study, ranging from $71 \%$ to $93 \%$ of eligible children (Figure 1). At baseline, study arms were balanced across demographic characteristics and had similar seroprevalence to measured pathogens (Table 1). As reported in previous studies [21,32], antibody responses to ETEC LTB and cholera CTB were highly cross-reactive (SI Figure 4). We excluded cholera CTB results from the primary analyses because we assumed that most of the responses reflected exposure to ETEC based on recent estimates of diarrhea etiology in nearby West African studies [33].

\section{Effects on malaria antibody response}

Children had high IgG seroprevalence to $P$. falciparum MSP-1 19 and AMA1 antigens, evidence of limited exposure to $P$. malariae, and evidence of very low exposure to $P$. vivax or $P$. ovale (Figure 2A). There was heterogeneity between study communities in the longer-lived MSP-119 and AMA1 antibodies, and overall seroprevalence to shorter-lived $P$. falciparum antibodies (GLURP-Ro, LSA1, CSP, HRP2) was considerably lower. IgG responses by age exhibited a characteristic pattern of waning up to 12 months, due to loss of maternal antibodies, with monotonic increases thereafter (SI Figure 1).

Children who received azithromycin had a transient reduction in $P$. falciparum IgG seroprevalence between ages 12-36 months (Figure 2B), but the overall difference between groups from ages 12-59 months was small $(-4 \%$ difference, $95 \% \mathrm{Cl}:-12 \%,+3 \% ; P=0.32)$. This corresponded to a $12 \%$ relative reduction in the hazard of seroconversion to any of the $P$. falciparum antigens $(\mathrm{HR}=0.88,95 \% \mathrm{Cl}$ : 0.62, 1.26). Antigen-specific differences between groups showed small, non-statistically significant reductions among children who received azithromycin based on seroprevalence (Figure 2C) and force of infection measured by the seroconversion rate (Figure 2D). Antigen-specific, age-seroprevalence curves showed similar overall patterns between groups, with largest reductions in $P$. falciparum AMA1 (SI Figure 5), consistent with comparisons of community-level means (SI Figure 6). 
medRxiv preprint doi: https://doi.org/10.1101/2021.04.23.21255957; this version posted April 26, 2021. The copyright holder for this preprint

(which was not certified by peer review) is the author/funder, who has granted medRxiv a license to display the preprint in perpetuity.

This article is a US Government work. It is not subject to copyright under 17 USC 105 and is also made available for use under a CCO license.

\section{Effects on bacterial and protozoan antibody response}

Campylobacter and ETEC seroprevalence were $>90 \%$ among children 6-24 months, with little heterogeneity between communities (Figure 3A). Salmonella serogroups B and D, Streptococcus serogroup A, Cryptosporidium, and Giardia seroprevalence was lower compared to the highest transmission pathogens and more heterogeneous between communities (Figure 3A). Many bacterial and protozoan pathogens showed evidence of maternal IgG contributions through age six months, and mean Campylobacter and Giardia IgG levels declined modestly beyond ages 18-24 months (SI Figure 2).

Campylobacter seroprevalence was lower among children who received azithromycin compared with placebo ( $91 \%$ vs $94 \%$, difference $=-3 \%, 95 \% \mathrm{Cl}:-5 \%,-1 \% ; P=0.03$ ) (Figure $3 \mathrm{C}$ ), and ageseroprevalence curves showed a consistent reduction across all ages (Figure 3B). We estimated 0.5 fewer Campylobacter seroconversions per child-year at risk, a 29\% relative reduction (1.30 versus 1.84 seroconversions per year), based on a semiparametric proportional hazards model $(H R=0.71,95 \%$ $\mathrm{Cl}$ : 0.66, 0.89; $P=0.004$ ), which remained significant after correction for multiple testing (Figure 3D). There were no statistically significant reductions in seroprevalence or force of infection for other measured bacterial and protozoan pathogens. Age-seroprevalence curves (SI Figure 7) and community level means (SI Figure 8) were consistent with the overall results.

\section{Additional analyses}

Children included in multiple cross-sectional samples between ages $12-59$ months contributed to longitudinal analyses of malaria seroconversion (919 children, 2,197 measurements). Longitudinal samples from children ages 6-59 months ( 1,038 children, 2,516 measurements) contributed to analyses 
medRxiv preprint doi: https://doi.org/10.1101/2021.04.23.21255957; this version posted April 26, 2021. The copyright holder for this preprint

(which was not certified by peer review) is the author/funder, who has granted medRxiv a license to display the preprint in perpetuity.

This article is a US Government work. It is not subject to copyright under 17 USC 105 and is also made available for use under a CCO license.

of Salmonella and Streptococcus, and longitudinal samples among children 6-24 months (313 children, 680 measurements) contributed to analyses of the remaining enteric pathogens. Seroconversion rates were generally higher when estimated longitudinally compared with those estimated from agestructured seroprevalence. Longitudinal analyses demonstrated larger reductions in $P$. falciparum seroconversion rates among children who received azithromycin compared to the primary analysis (e.g., AMA1 seroconversion incidence rate ratio: $0.49,95 \% \mathrm{Cl}: 0.31,0.76)$, but most comparisons were slightly underpowered given the small size of the longitudinal cohort (SI Table 1). Longitudinal comparisons of bacterial and protozoan pathogens were largely consistent with the primary analysis but were also slightly underpowered. For example, the Campylobacter seroconversion rate was $19 \%$ lower (IRR: $0.81,95 \% \mathrm{Cl}: 0.62,1.04)$ in the azithromycin group compared to placebo in the longitudinal analysis (SI Table 1). Longitudinal analyses showed seroreversion across all antibodies measured except for responses to Campylobacter and ETEC, with some evidence for higher Cryptosporidium and Giardia seroreversion rates in the azithromycin group (SI Table 2).

There was no evidence for effect modification by study phase (SI Figure 9) or child age at trial start (SI Figure 10).

\section{Discussion}

In this analysis of IgG antibody response to malarial, bacterial, and protozoan pathogens we found that biannual mass distribution of azithromycin to children 1-59 months reduced Campylobacter seroprevalence and seroconversion rates. Overall, azithromycin had limited effects on antibody-based measures of pathogen exposure against a backdrop of very high transmission for most pathogens. Antibody responses showed that infection was extremely common for most pathogens studied, for 
medRxiv preprint doi: https://doi.org/10.1101/2021.04.23.21255957; this version posted April 26, 2021. The copyright holder for this preprint

(which was not certified by peer review) is the author/funder, who has granted medRxiv a license to display the preprint in perpetuity.

This article is a US Government work. It is not subject to copyright under 17 USC 105 and is also made available for use under a CCO license.

example, seroprevalence to Campylobacter and ETEC was close to $100 \%$ by age 18 months, and was $>90 \%$ for $P$. falciparum by age 40 months.

A reduction in IgG responses to Campylobacter jejuni among children who received azithromycin is consistent with the trial's earlier report of reduced mortality in azithromycin-treated communities attributed to dysentery [3]. The results are also consistent with a separate metagenomic deep sequencing analysis of rectal swabs collected from children in the same communities, which showed a reduction in Campylobacter upsaliensis carriage but no other differences in gut microbiome composition among children in azithromycin-treated communities [5]. IgG responses p18 and p39 could reflect previous infections from multiple Campylobacter species. A rabbit polyclonal antibody raised against recombinant p18 antigen cross reacted with an 18-kDa protein in cell extracts from a broad selection of other Campylobacter species [34], and the high level of amino acid sequence identity predicted by a Basic Local Alignment Search Tool for Proteins (BLASTP) analysis [35,36] of the C. jejuni and C. upsaliensis p18 and p39 antigens (88\% and $80 \%$, respectively) suggests that measured IgG responses could reflect previous infection by one or both species (SI Table 3). Although we estimated that azithromycin treatment reduced the hazard of Campylobacter seroconversion by $29 \%$, by age 18 months more than $95 \%$ of children in both groups were seropositive to Campylobacter, reflecting very high force of infection. These results are consistent with eight, high-resolution, longitudinal cohorts that found $85 \%$ of children in low-resource settings had experienced at least one Campylobacter infection by age 12 months [37]. Campylobacter infections among preschool aged children have significant clinical sequelae including acute bloody diarrhea (identified as the leading cause) [38], increases in intestinal inflammatory markers [37], and subsequent growth failure [39]. As we describe below, features of this study could have led us to under-estimate effects of the intervention on pathogen carriage, so effects demonstrated on Campylobacter force of infection despite built-in 
medRxiv preprint doi: https://doi.org/10.1101/2021.04.23.21255957; this version posted April 26, 2021. The copyright holder for this preprint

(which was not certified by peer review) is the author/funder, who has granted medRxiv a license to display the preprint in perpetuity.

This article is a US Government work. It is not subject to copyright under 17 USC 105 and is also made available for use under a CCO license.

conservatism in the estimates suggest a potentially important mechanism for the intervention's effect on mortality in Niger.

This study illustrates how multiplex antibody assays can measure intervention effects across diverse pathogens at relatively low cost and from samples that are relatively easy to collect [40]. Multiplex assays are especially valuable for interventions like azithromycin, which could plausibly have broadbased impacts. Previous results from this trial found that azithromycin reduced mortality attributed to malaria, diarrhea, dysentery, and pneumonia [3], and reduced malaria parasitemia [4]. Yet, our finding of no clear reduction in IgG responses to malaria and bacterial pathogens beyond Campylobacter suggests that in high transmission settings, infrequent IgG measurements by themselves are potentially an insensitive trial endpoint. Azithromycin has modest activity against $P$. falciparum through action against the parasite's apicoplast $[7,8]$, and high efficacy against $P$. vivax both as a prophylactic to prevent infection [9] and as a treatment therapy [10]. Azithromycin has broad-spectrum activity against gram-positive and atypical bacteria and has been shown to be highly effective for treatment of bacterial enteric pathogen infections, including enterotoxigenic Escherichia coli (ETEC), Vibrio cholerae, and non-typhoidal Salmonella enterica [12-14]. Several trials have demonstrated that azithromycin has comparable efficacy to penicillin in treating group A streptococcal pharyngitis [11]. Azithromycin has been shown to have modest anti-parasitic activity against Cryptosporidium parvum [15]. Less is known about its effect on Giardia duodenalis infections in humans, but in vitro and in vivo animal studies have shown azithromycin had comparable antimicrobial activity against $G$. duodenalis to metronizadole (the first line treatment) [16] and small scale (uncontrolled) human studies suggest cure rates in excess of $90 \%$ [17]. Yet, even if azithromycin successfully treated infections from these pathogens, IgG responses might be an insensitive marker of efficacy if treatment did not reduce the immune response or if a child was reinfected between the 6-month community-based treatments, leading to a boost in 
medRxiv preprint doi: https://doi.org/10.1101/2021.04.23.21255957; this version posted April 26, 2021. The copyright holder for this preprint

(which was not certified by peer review) is the author/funder, who has granted medRxiv a license to display the preprint in perpetuity.

This article is a US Government work. It is not subject to copyright under 17 USC 105 and is also made available for use under a CCO license.

IgG levels. Additionally, IgG longevity or low-density infections that elicited a robust adaptive immune response could explain the small reductions observed in $P$. falciparum IgG responses despite lower levels of parasitemia and parasite density in the azithromycin group [4].

This study had limitations, all of which could have led us to under-estimate effects of azithromycin on pathogen-induced IgG response. Most samples were collected at the end of the dry season, many months after peak malaria season, which coincides with seasonal rains (SI Figure 3). Subgroup analyses by study phase compared groups at 6-months after enrollment, immediately following the rainy season, and showed no consistently larger effect across antigens at that timepoint (SI Figure 9), suggesting that measurement timing alone would not explain the absence of effects on malaria and other pathogens. A second limitation was that the study collected blood spots approximately 6 months after each treatment administration. If azithromycin had short term effects on infection and antibody response, without effects on longer term pathogen carriage, then this study could have missed such transient effects. The timing of monitoring visits was chosen to provide longer-term data about community antibiotic resistance (i.e., resistance that persisted even months after the mass drug administration) [6]. However, azithromycin would be expected to have its strongest effect within days or weeks of administration. An analysis of timing of mortality in MORDOR Niger suggested that most of the intervention effect occurred within three months of distribution [41]. Among children ages 0-24 months, macrolides have been shown to reduce the risk of Campylobacter detection in stool significantly 0-15 days after treatment with reduced protection through 45 days, and no protection thereafter [37]. A third limitation was that the primary analysis followed the repeated cross-sectional design and thus did not account for high levels of between-child variability in IgG response. Repeated cross-sectional samples enabled the trial to continually enroll young children as the study progressed and was protected from potential bias through loss-to follow-up. Nevertheless, longitudinal analyses on 
medRxiv preprint doi: https://doi.org/10.1101/2021.04.23.21255957; this version posted April 26, 2021. The copyright holder for this preprint

(which was not certified by peer review) is the author/funder, who has granted medRxiv a license to display the preprint in perpetuity.

This article is a US Government work. It is not subject to copyright under 17 USC 105 and is also made available for use under a CCO license.

a subset of the children who provided multiple specimens over time had similar precision as the primary analysis, illustrating much higher efficiency of longitudinal designs for lgG responses. Despite this limitation, high levels of agreement between the repeated cross-sectional and longitudinal analyses provided a valuable internal consistency check. Finally, the campaign-style distribution of azithromycin every 6 months meant that some children would have been up to 6-months old before their first treatment. For very high transmission pathogens, it is likely that many children had already been infected and may have had a robust IgG response that was insensitive to reduced pathogen carriage following azithromycin treatment.

In conclusion, this study demonstrated that biannual mass distribution of azithromycin reduced antibody-based measures of Campylobacter infection, consistent with independent metagenomic analyses in the same study communities. There was no evidence for significant reductions in IgG antibody-based measures of infection with malaria or other measured bacterial and protozoan pathogens. Given the clinically significant sequelae from Campylobacter infection among preschoolaged children, our results point to at least one important mechanism through which azithromycin plausibly reduced mortality in Niger. Studies of infection in the weeks immediately following treatment may provide additional insights into the mechanisms through which mass distribution of azithromycin reduces child mortality.

\section{Acknowledgements}

Funding: This work was supported by the Bill \& Melinda Gates Foundation (award no. OPP1032340 to $T M L)$ and was supported in part by an unrestricted grant from Research to Prevent Blindness and by the National Institute of Allergy and Infectious Diseases (award no. K01-Al119180 to BFA). The 
Gates Foundation approved the study design, but had no role in data collection, data analysis, data interpretation, or writing of the report.

Author contributions: following CRediT taxonomy, conceptualization (DLM, ER, TML, JDK, BFA), data curation (JDK, VL, BFA), formal analysis (BFA), funding acquisition (TML), investigation (DLM, ER, JWP, BFA), methodology (BFA), project administration (AMA, RM, EL, TML), resources (JWP, DLM, ER, EBG), software (BFA, TCP, VL), supervision (AMA, RM, EL, KSO), validation (EBG, ER), visualization (BFA), Writing - Original Draft Preparation (AMA, BFA, DLM, EBG), Writing - Review \& Editing (AMA, RM, EBG, ER, JWP, EL, KSO, VL, CEO, JDK, TCP, TD, TML, DLM, BFA).

Competing interests: The authors declare no competing interests. The findings and conclusions in this article are those of the authors and do not necessarily represent the official position of the Centers for Disease Control and Prevention. Use of trade names is for identification only and does not imply endorsement by the Public Health Service or by the U.S. Department of Health and Human Services. 
medRxiv preprint doi: https://doi.org/10.1101/2021.04.23.21255957; this version posted April 26, 2021. The copyright holder for this preprint

(which was not certified by peer review) is the author/funder, who has granted medRxiv a license to display the preprint in perpetuity.

This article is a US Government work. It is not subject to copyright under 17 USC 105 and is also made available for use under a CCO license.

\section{MORDOR-Niger Study Group Investigators}

\section{University of California, San Francisco, San Francisco, CA, USA}

Benjamin F Arnold, Catherine Cook, Sun Y Cotter, Thuy Doan, Dionna M Fry, Jeremy D Keenan, Victoria Le, Elodie Lebas, Thomas M Lietman, Ying Lin, Kieran S O’Brien, Catherine E Oldenburg, Travis C Porco, Kathryn J Ray, Philip J Rosenthal, George W Rutherford, Benjamin Vanderschelden, Nicole E Varnado, Lina Zhong, Zhaoxia Zhou

The Carter Center, Atlanta, GA, USA

E Kelly Callahan, Aisha E Stewart

\section{The Carter Center Niger, Niamey, Niger}

Ahmed M Arzika, Sanoussi Elh Adamou, Nana Fatima Galo, Fatima Ibrahim, Salissou Kane, Mariama Kiemago, Ramatou Maliki

\section{Programme National de Santé Oculaire, Niamey, Niger}

Amza Abdou, Boubacar Kadri, Nassirou Beido

Johns Hopkins University, Baltimore, MD, USA

Jerusha Weaver, Sheila K West

International Trachoma Initiative, Decatur, GA, USA

Paul M Emerson

Steering Committee. The steering committee for the trial consisted of Robin L Bailey, Jeremy $D$ Keenan, Thomas M Lietman, Travis C Porco, and Sheila K West.

Sponsor program officers. The program officers from the trial's sponsor included Rasa Izadnegahdar, Julie Jacobson, Thomas Kanyok, and Erin Shutes (Bill \& Melinda Gates Foundation, Seattle, WA, USA).

Data and Safety Monitoring Committee (DSMC). The trial's DSMC included Judd L Walson (University of Washington, Seattle, WA, USA), Allen W Hightower (Centers for Disease Control and Prevention, Atlanta, GA, USA), Emily E Anderson (Loyola University, Chicago, IL, USA), Wondu Alemayehu (Fred Hollows Foundation, Addis Ababa, Ethiopia), and Latha Rajan (Tulane University, New Orleans, LA, USA). 
medRxiv preprint doi: https://doi.org/10.1101/2021.04.23.21255957; this version posted April 26, 2021. The copyright holder for this preprint

(which was not certified by peer review) is the author/funder, who has granted medRxiv a license to display the preprint in perpetuity.

This article is a US Government work. It is not subject to copyright under 17 USC 105 and is also made available for use under a CCO license.

\section{References}

1. Golding N, Burstein R, Longbottom J, Browne AJ, Fullman N, Osgood-Zimmerman A, et al. Mapping under-5 and neonatal mortality in Africa, 2000-15: a baseline analysis for the Sustainable Development Goals. Lancet Lond Engl. 2017;390: 2171-2182. doi:10.1016/S01406736(17)31758-0

2. Keenan JD, Bailey RL, West SK, Arzika AM, Hart J, Weaver J, et al. Azithromycin to Reduce Childhood Mortality in Sub-Saharan Africa. N Engl J Med. 2018;378: 1583-1592. doi:10.1056/NEJMoa1715474

3. Keenan JD, Arzika AM, Maliki R, Elh Adamou S, Ibrahim F, Kiemago M, et al. Cause-specific mortality of children younger than 5 years in communities receiving biannual mass azithromycin treatment in Niger: verbal autopsy results from a cluster-randomised controlled trial. Lancet Glob Health. 2020;8: e288-e295. doi:10.1016/S2214-109X(19)30540-6

4. Arzika AM, Maliki R, Boubacar N, Kane S, Cotter SY, Lebas E, et al. Biannual mass azithromycin distributions and malaria parasitemia in pre-school children in Niger: A cluster-randomized, placebo-controlled trial. PLoS Med. 2019;16: e1002835. doi:10.1371/journal.pmed.1002835

5. Doan T, Hinterwirth A, Worden L, Arzika AM, Maliki R, Abdou A, et al. Gut microbiome alteration in MORDOR I: a community-randomized trial of mass azithromycin distribution. Nat Med. 2019;25: 1370-1376. doi:10.1038/s41591-019-0533-0

6. Doan T, Worden L, Hinterwirth A, Arzika AM, Maliki R, Abdou A, et al. Macrolide and Nonmacrolide Resistance with Mass Azithromycin Distribution. N Engl J Med. 2020;383: 1941-1950. doi:10.1056/NEJMoa2002606

7. Sidhu ABS, Sun Q, Nkrumah LJ, Dunne MW, Sacchettini JC, Fidock DA. In vitro efficacy, resistance selection, and structural modeling studies implicate the malarial parasite apicoplast as the target of azithromycin. J Biol Chem. 2007;282: 2494-2504. doi:10.1074/jbc.M608615200

8. Dahl EL, Rosenthal PJ. Multiple antibiotics exert delayed effects against the Plasmodium falciparum apicoplast. Antimicrob Agents Chemother. 2007;51: 3485-3490. doi:10.1128/AAC.00527-07

9. Taylor WR, Richie TL, Fryauff DJ, Picarima H, Ohrt C, Tang D, et al. Malaria prophylaxis using azithromycin: a double-blind, placebo-controlled trial in Irian Jaya, Indonesia. Clin Infect Dis Off Publ Infect Dis Soc Am. 1999;28: 74-81. doi:10.1086/515071

10. Dunne MW, Singh N, Shukla M, Valecha N, Bhattacharyya PC, Patel K, et al. A double-blind, randomized study of azithromycin compared to chloroquine for the treatment of Plasmodium vivax malaria in India. Am J Trop Med Hyg. 2005;73: 1108-1111.

11. van Driel ML, De Sutter Al, Habraken $H$, Thorning S, Christiaens T. Different antibiotic treatments for group A streptococcal pharyngitis. Cochrane Database Syst Rev. 2016;9: CD004406. doi:10.1002/14651858.CD004406.pub4 
medRxiv preprint doi: https://doi.org/10.1101/2021.04.23.21255957; this version posted April 26, 2021. The copyright holder for this preprint

(which was not certified by peer review) is the author/funder, who has granted medRxiv a license to display the preprint in perpetuity.

This article is a US Government work. It is not subject to copyright under 17 USC 105 and is also made available for use under a CCO license.

12. Kuschner RA, Trofa AF, Thomas RJ, Hoge CW, Pitarangsi C, Amato S, et al. Use of azithromycin for the treatment of Campylobacter enteritis in travelers to Thailand, an area where ciprofloxacin resistance is prevalent. Clin Infect Dis Off Publ Infect Dis Soc Am. 1995;21: 536-541. doi:10.1093/clinids/21.3.536

13. Tribble DR. Antibiotic Therapy for Acute Watery Diarrhea and Dysentery. Mil Med. 2017;182: 1725. doi:10.7205/MILMED-D-17-00068

14. Saha D, Karim MM, Khan WA, Ahmed S, Salam MA, Bennish ML. Single-dose azithromycin for the treatment of cholera in adults. $N$ Engl J Med. 2006;354: 2452-2462. doi:10.1056/NEJMoa054493

15. Checkley W, White AC Jr, Jaganath D, Arrowood MJ, Chalmers RM, Chen X-M, et al. A review of the global burden, novel diagnostics, therapeutics, and vaccine targets for cryptosporidium. Lancet Infect Dis. 2015;15: 85-94. doi:10.1016/S1473-3099(14)70772-8

16. Gardner TB, Hill DR. Treatment of giardiasis. Clin Microbiol Rev. 2001;14: 114-128. doi:10.1128/CMR.14.1.114-128.2001

17. Jeske J, Malinowska B, Kamerys J, Lipowczan G, Olszewska A, Ochęcka-Szymańska A. Effectiveness of azithromycin in the treatment of giardiasis. Med Sci Monit. 1998;4: 547-550.

18. Nuzzo R. How scientists fool themselves - and how they can stop. Nature. 2015;526: $182-185$. doi:10.1038/526182a

19. Goodhew EB, Priest JW, Moss DM, Zhong G, Munoz B, Mkocha H, et al. CT694 and pgp3 as serological tools for monitoring trachoma programs. PLoS Negl Trop Dis. 2012;6: e1873. doi:10.1371/journal.pntd.0001873

20. Priest JW, Plucinski MM, Huber CS, Rogier E, Mao B, Gregory CJ, et al. Specificity of the IgG antibody response to Plasmodium falciparum, Plasmodium vivax, Plasmodium malariae, and Plasmodium ovale MSP119 subunit proteins in multiplexed serologic assays. Malar J. 2018;17: 417. doi:10.1186/s12936-018-2566-0

21. Arnold BF, Martin DL, Juma J, Mkocha H, Ochieng JB, Cooley GM, et al. Enteropathogen antibody dynamics and force of infection among children in low-resource settings. eLife. 2019;8: e45594. doi:10.7554/eLife.45594

22. Mues KE, Lammie PJ, Klein M, Kleinbaum DG, Addiss D, Fox LM. Changes in Antibody Levels during and following an Episode of Acute Adenolymphangitis (ADL) among Lymphedema Patients in Léogâne, Haiti. PloS One. 2015;10: e0141047. doi:10.1371/journal.pone.0141047

23. Zinkernagel RM. Maternal antibodies, childhood infections, and autoimmune diseases. N Engl J Med. 2001;345: 1331-1335. doi:10.1056/NEJMra012493

24. Wood S. Generalized Additive Models: An Introduction with R. Second. Chapman and Hall/CRC; 2017. 
medRxiv preprint doi: https://doi.org/10.1101/2021.04.23.21255957; this version posted April 26, 2021. The copyright holder for this preprint

(which was not certified by peer review) is the author/funder, who has granted medRxiv a license to display the preprint in perpetuity.

This article is a US Government work. It is not subject to copyright under 17 USC 105 and is also made available for use under a CCO license.

25. Shkedy Z, Aerts M, Molenberghs G, Beutels P, Van Damme P. Modelling age-dependent force of infection from prevalence data using fractional polynomials. Stat Med. 2006;25: 1577-1591. doi:10.1002/sim.2291

26. Wood S. mgcv:Mixed GAM Computation Vehicle with GCV/AIC/REML smoothness estimation. University of Bath; 2012. Available: http://opus.bath.ac.uk/32507/

27. Ruppert D, Wand MP, Carroll RJ. Semiparametric Regression. Cambridge University Press; 2003. Available: https://market.android.com/details?id=book-Y4uEvXFP2voC

28. Arnold BF, Kanyi H, Njenga SM, Rawago FO, Priest JW, Secor WE, et al. Fine-scale heterogeneity in Schistosoma mansoni force of infection measured through antibody response. Proc Natl Acad Sci U S A. 2020;117: 23174-23181. doi:10.1073/pnas.2008951117

29. Doan T, Arzika AM, Hinterwirth A, Maliki R, Zhong L, Cummings S, et al. Macrolide Resistance in MORDOR I - A Cluster-Randomized Trial in Niger. N Engl J Med. 2019;380: 2271-2273. doi:10.1056/NEJMc1901535

30. Hayes RJ, Moulton LH. Cluster randomised trials. 2nd Edition. Boca Raton, FL: Taylor \& Francis Group; 2017.

31. Benjamini Y, Hochberg Y. Controlling the False Discovery Rate: A Practical and Powerful Approach to Multiple Testing. J R Stat Soc Ser B Methodol. 1995;57: 289-300. doi:10.1111/j.25176161.1995.tb02031.x

32. Smith NW, Sack RB. Immunologic cross-reactions of enterotoxins from Escherichia coli and Vibrio cholerae. J Infect Dis. 1973;127: 164-170.

33. Kotloff KL, Nasrin D, Blackwelder WC, Wu Y, Farag T, Panchalingham S, et al. The incidence, aetiology, and adverse clinical consequences of less severe diarrhoeal episodes among infants and children residing in low-income and middle-income countries: a 12-month case-control study as a follow-on to the Global Enteric Multicenter Study (GEMS). Lancet Glob Health. 2019;7: e568e584. doi:10.1016/S2214-109X(19)30076-2

34. Burnens A, Stucki U, Nicolet J, Frey J. Identification and characterization of an immunogenic outer membrane protein of Campylobacter jejuni. J Clin Microbiol. 1995;33: 2826-2832.

35. Altschul SF, Madden TL, Schäffer AA, Zhang J, Zhang Z, Miller W, et al. Gapped BLAST and PSIBLAST: a new generation of protein database search programs. Nucleic Acids Res. 1997;25: 3389-3402. doi:10.1093/nar/25.17.3389

36. Altschul SF, Wootton JC, Gertz EM, Agarwala R, Morgulis A, Schäffer AA, et al. Protein database searches using compositionally adjusted substitution matrices. FEBS J. 2005;272: 5101-5109. doi:10.1111/j.1742-4658.2005.04945.x

37. Amour C, Gratz J, Mduma E, Svensen E, Rogawski ET, McGrath M, et al. Epidemiology and Impact of Campylobacter Infection in Children in 8 Low-Resource Settings: Results From the MALED Study. Clin Infect Dis. 2016;63: 1171-1179. doi:10.1093/cid/ciw542 
medRxiv preprint doi: https://doi.org/10.1101/2021.04.23.21255957; this version posted April 26, 2021. The copyright holder for this preprint

(which was not certified by peer review) is the author/funder, who has granted medRxiv a license to display the preprint in perpetuity.

This article is a US Government work. It is not subject to copyright under 17 USC 105 and is also made available for use under a CCO license.

38. Platts-Mills JA, Babji S, Bodhidatta L, Gratz J, Haque R, Havt A, et al. Pathogen-specific burdens of community diarrhoea in developing countries: a multisite birth cohort study (MAL-ED). Lancet Glob Health. 2015;3: e564-e575. doi:10.1016/S2214-109X(15)00151-5

39. Rogawski ET, Liu J, Platts-Mills JA, Kabir F, Lertsethtakarn P, Siguas M, et al. Use of quantitative molecular diagnostic methods to investigate the effect of enteropathogen infections on linear growth in children in low-resource settings: longitudinal analysis of results from the MAL-ED cohort study. Lancet Glob Health. 2018. doi:10.1016/S2214-109X(18)30351-6

40. Arnold BF, Scobie HM, Priest JW, Lammie PJ. Integrated Serologic Surveillance of Population Immunity and Disease Transmission. Emerg Infect Dis. 2018;24: 1188-1194. doi:10.3201/eid2407.171928

41. Porco TC, Hart J, Arzika AM, Weaver J, Kalua K, Mrango Z, et al. Mass Oral Azithromycin for Childhood Mortality: Timing of Death After Distribution in the MORDOR Trial. Clin Infect Dis Off Publ Infect Dis Soc Am. 2019;68: 2114-2116. doi:10.1093/cid/ciy973 
medRxiv preprint doi: https://doi.org/10.1101/2021.04.23.21255957; this version posted April 26, 2021. The copyright holder for this preprint

(which was not certified by peer review) is the author/funder, who has granted medRxiv a license to display the preprint in perpetuity.

This article is a US Government work. It is not subject to copyright under 17 USC 105 and is also made available for use under a CCO license.

\section{Tables}

Table 1. Baseline study group characteristics.

\begin{tabular}{|c|c|c|}
\hline & $\begin{array}{l}\text { Placebo } \\
N=15\end{array}$ & $\begin{array}{c}\text { Azithromycin } \\
\mathrm{N}=15\end{array}$ \\
\hline Number of children 0-59 months & 559 & 555 \\
\hline \multicolumn{3}{|l|}{ Age, $\%$} \\
\hline $0 \mathrm{y}$ & 13 & 12 \\
\hline $1 \mathrm{y}$ & 14 & 14 \\
\hline $2 \mathrm{y}$ & 18 & 20 \\
\hline $3 y$ & 26 & 24 \\
\hline $4 \mathrm{y}$ & 30 & 30 \\
\hline Female, \% & 45 & 48 \\
\hline \multicolumn{3}{|l|}{ Malaria seroprevalence, \% * } \\
\hline P. falciparum MSP-1 19 & 79 & 76 \\
\hline P. falciparum AMA1 & 67 & 61 \\
\hline P. falciparum GLURP-Ro & 26 & 21 \\
\hline P. falciparum LSA1 & 11 & 8 \\
\hline P. falciparum CSP & 5 & 4 \\
\hline P. falciparum HRP2 & 2 & 2 \\
\hline P. malariae MSP-1 19 & 13 & 12 \\
\hline P. ovale MSP-1 19 & 2 & 3 \\
\hline P. vivax MSP-1 19 & 1 & 2 \\
\hline \multicolumn{3}{|l|}{ Bacteria and protozoa seroprevalence, $\%^{\dagger}$} \\
\hline Campylobacter sp. p18 or p39 & 92 & 91 \\
\hline ETEC LTB & 88 & 84 \\
\hline Salmonella sp. LPS serogroups B or D & 48 & 45 \\
\hline Cryptosporidium sp. Cp17 or Cp23 & 85 & 83 \\
\hline Giardia sp. VSP-3 or VSP-5 & 77 & 76 \\
\hline Streptococcus sp. serogroup A SPEB & 63 & 60 \\
\hline
\end{tabular}

* Malaria antibody seroprevalence estimated among children ages $12-59$ months (baseline Placebo $N=488$, Azithromycin $N=486$ ), per the age group used in the primary analysis.

† Bacteria and protozoan antibody seroprevalence estimated among children ages 6-24 months (ETEC LTB, baseline Placebo $N=201$, Azithromycin $N=202$ ) or among children ages 6-59 months (all others, baseline Placebo $N=532$, Azithromycin $N=539$ ) or, per the age groups used in the primary analysis.

$\ddagger$ Created with notebook https://osf.io/qeg4u 
medRxiv preprint doi: https://doi.org/10.1101/2021.04.23.21255957; this version posted April 26, 2021. The copyright holder for this preprint (which was not certified by peer review) is the author/funder, who has granted medRxiv a license to display the preprint in perpetuity.

This article is a US Government work. It is not subject to copyright under 17 USC 105 and is also made available for use under a CCO license.

Enrollment

Allocation
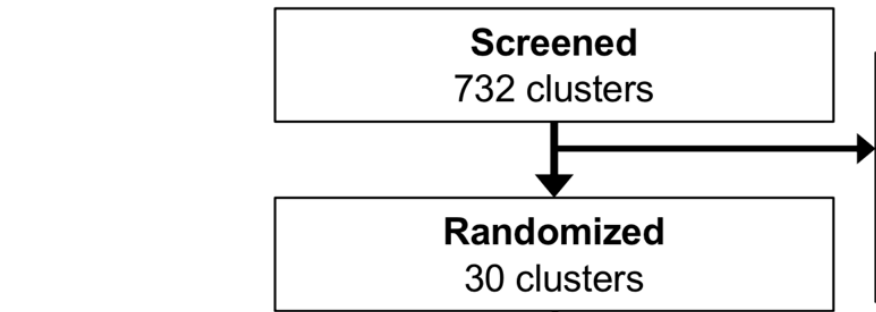

\begin{tabular}{|c|}
\hline Excluded \\
Ineligible \\
86 clusters \\
Enrolled in other studies \\
616 clusters \\
\hline
\end{tabular}

Biannual Azithromycin

15 clusters

\section{Follow-up}

\begin{tabular}{c} 
Biannual Placebo \\
15 clusters \\
\hline
\end{tabular}
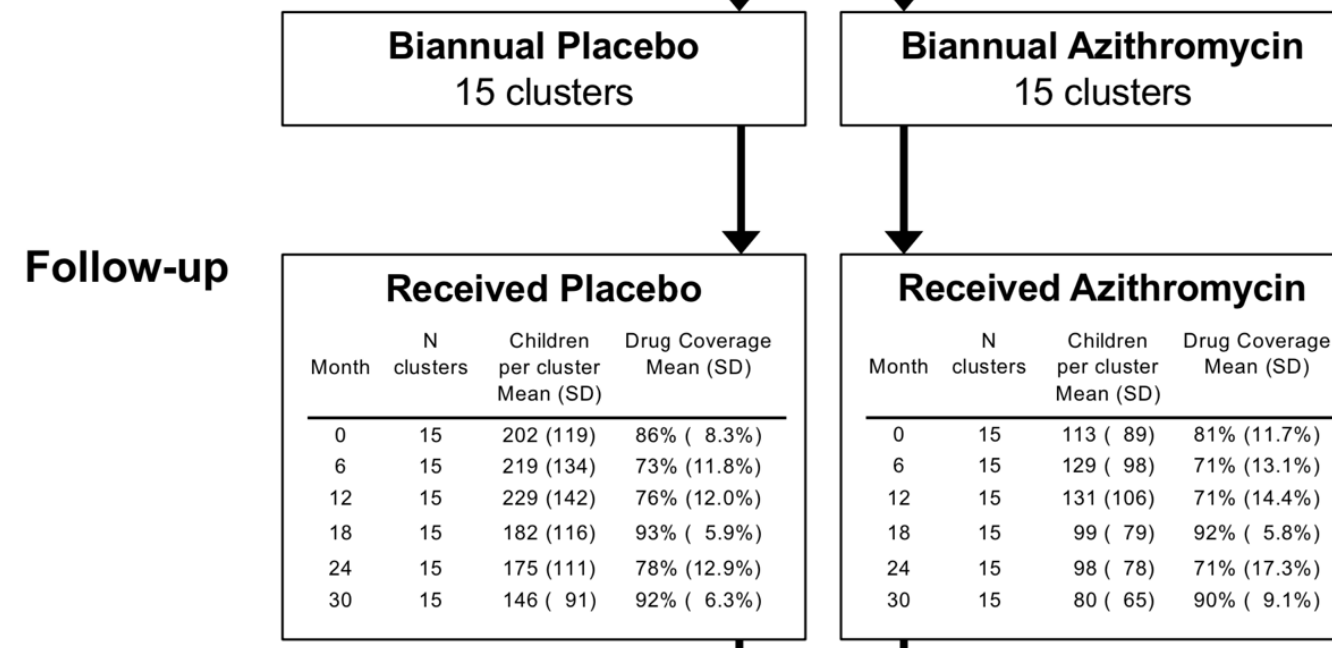

\begin{tabular}{cccc} 
Month & $\begin{array}{c}N \\
\text { clusters }\end{array}$ & $\begin{array}{c}\text { Children } \\
\text { per cluster } \\
\text { Mean (SD) }\end{array}$ & $\begin{array}{c}\text { Drug Coverage } \\
\text { Mean (SD) }\end{array}$ \\
\hline 0 & 15 & $113(89)$ & $81 \%(11.7 \%)$ \\
6 & 15 & $129(98)$ & $71 \%(13.1 \%)$ \\
12 & 15 & $131(106)$ & $71 \%(14.4 \%)$ \\
18 & 15 & $99(79)$ & $92 \%(5.8 \%)$ \\
24 & 15 & $98(78)$ & $71 \%(17.3 \%)$ \\
30 & 15 & $80(65)$ & $90 \%(9.1 \%)$
\end{tabular}

\section{Analysis}

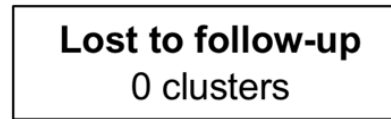

Excl. from analysis

0 clusters

129 children $<6 \mathrm{~m}$

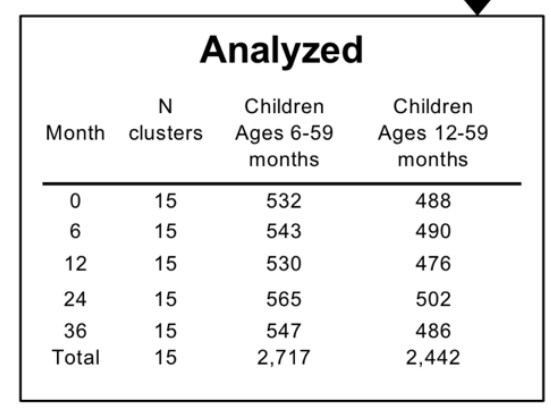

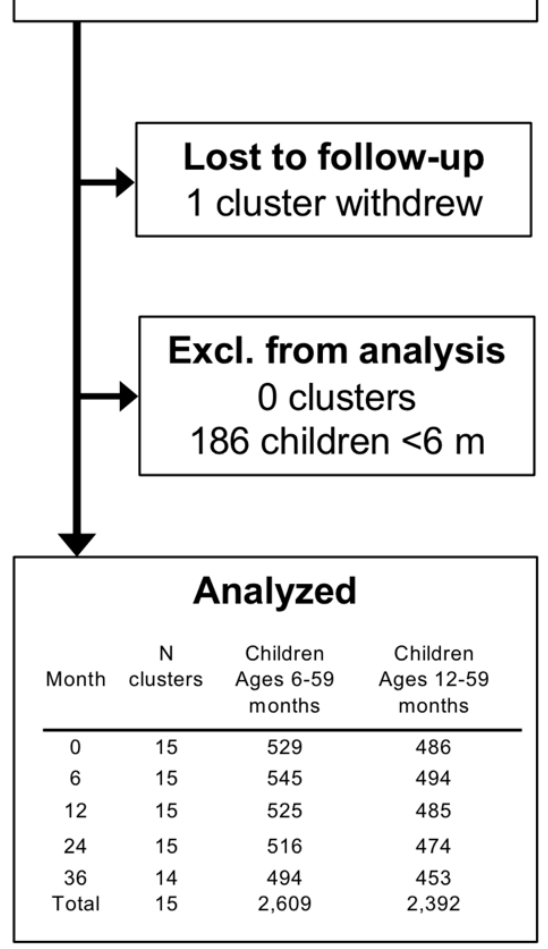

Figure 1. Study participant flow. 30 community clusters were randomly selected from a larger pool of clusters enrolled in the overall MORDOR Niger trial. A random sample of 40 children per community were selected for monitoring. Children $<12$ months old (malaria antigens) and $<6$ months (other antigens) were excluded from the primary analyses based on a pre-specified criteria to exclude maternal IgG contributions. Created with notebook https://osf.io/utxv3 . 
medRxiv preprint doi: https://doi.org/10.1101/2021.04.23.21255957; this version posted April 26, 2021. The copyright holder for this preprint (which was not certified by peer review) is the author/funder, who has granted medRxiv a license to display the preprint in perpetuity.

This article is a US Government work. It is not subject to copyright under 17 USC 105 and is also made available for use under a CCO license.

A

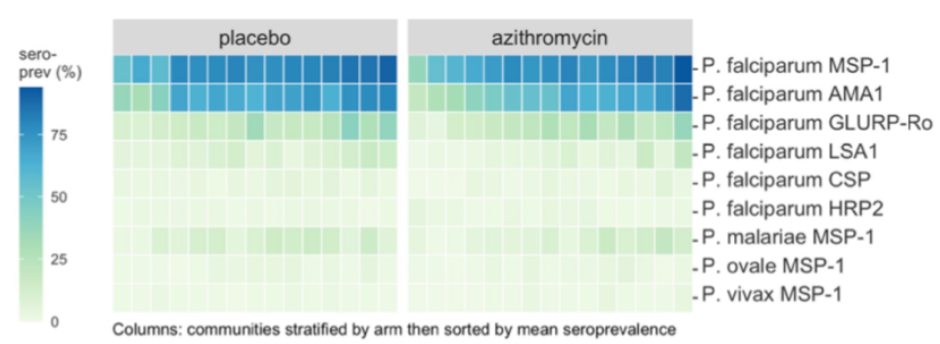

C

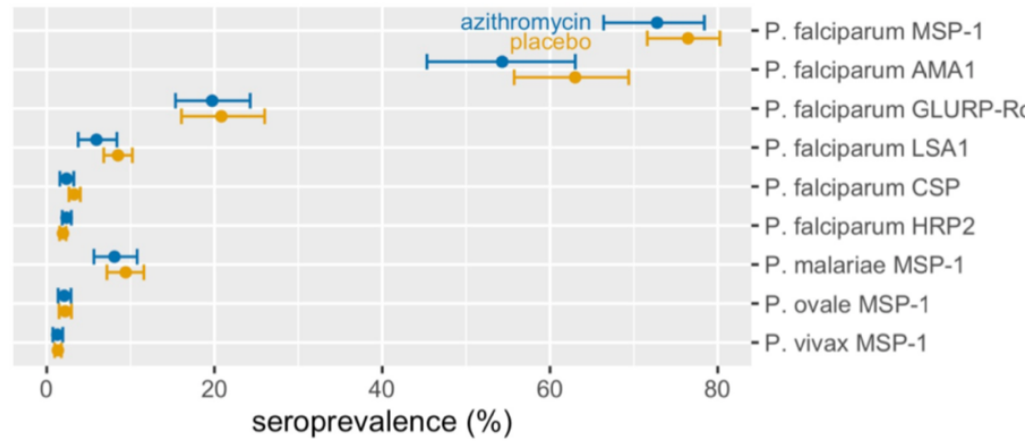

D

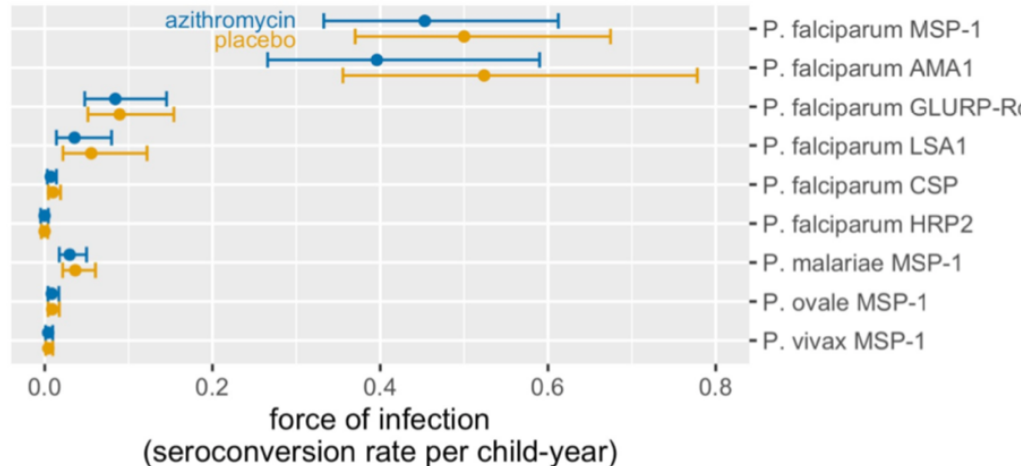

(seroconversion rate per child-year)
B
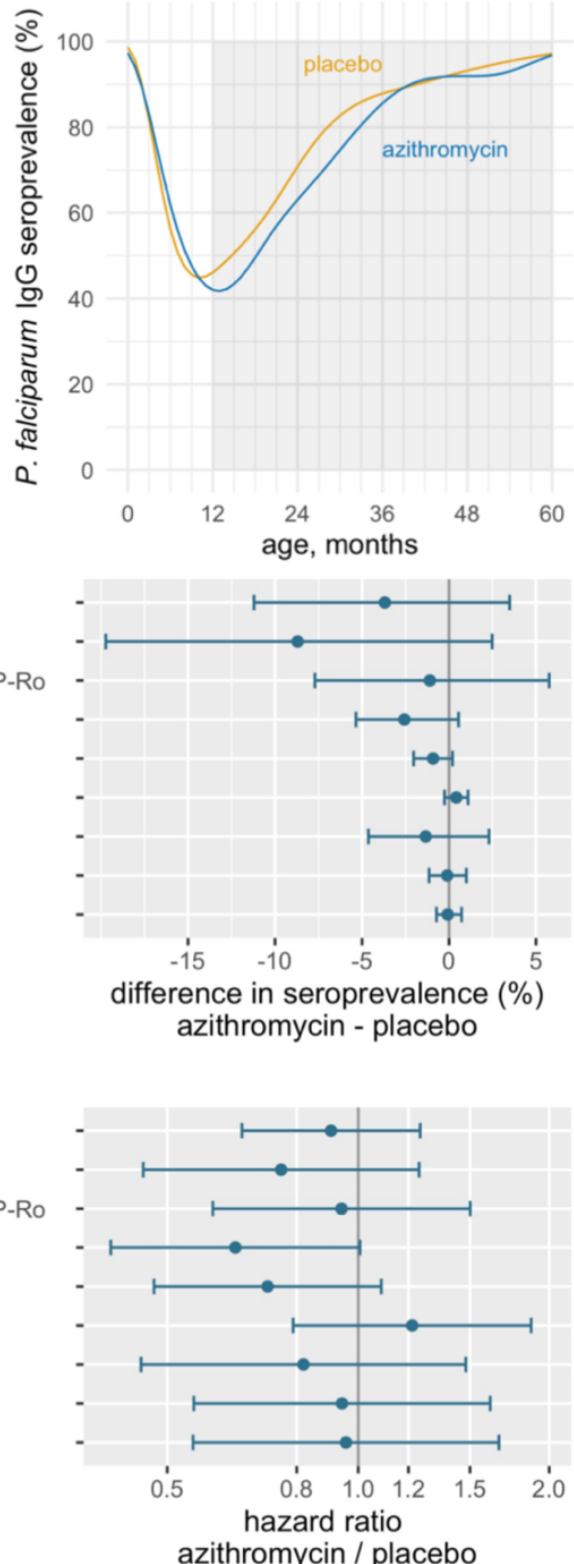

Figure 2. Malarial IgG antibody responses among preschool aged children in the MORDOR Niger trial, 2015-2018. (A) Community-level seroprevalence to malarial antigens. Columns represent individual communities, which were stratified by treatment group and then sorted by overall mean seroprevalence. (B) Seroprevalence to $P$. falciparum (positive to any measured antigen) by age and treatment arm, estimated with semiparametric splines. The shaded region from 12-59 months indicates the age range included in the primary analysis. (C) Antigen-specific lgG seroprevalence by treatment arm and difference between arms. (D). Antigen-specific force of infection estimated by the seroconversion rate, and hazard ratio for comparison between arms. No between-group comparisons were statistically significant at the 95\% confidence level after FDR correction. Created with notebooks https://osf.io/b2v3r, https://osf.io/37ybm, https://osf.io/fwxn5, which include detailed point estimates, and additional, consistent results based on geometric mean IgG levels. 
medRxiv preprint doi: https://doi.org/10.1101/2021.04.23.21255957; this version posted April 26, 2021. The copyright holder for this preprint (which was not certified by peer review) is the author/funder, who has granted medRxiv a license to display the preprint in perpetuity.

This article is a US Government work. It is not subject to copyright under 17 USC 105 and is also made available for use under a CCO license.

A

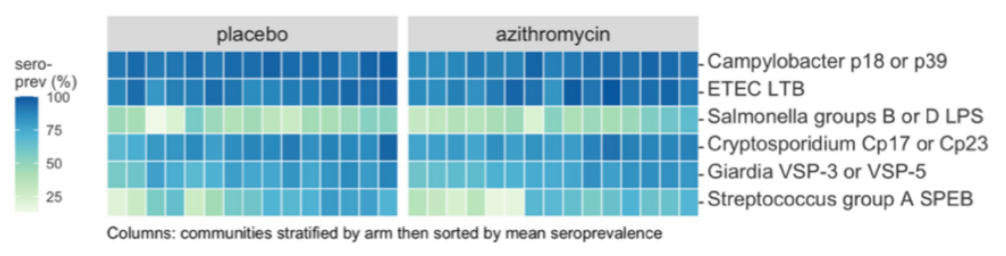

C

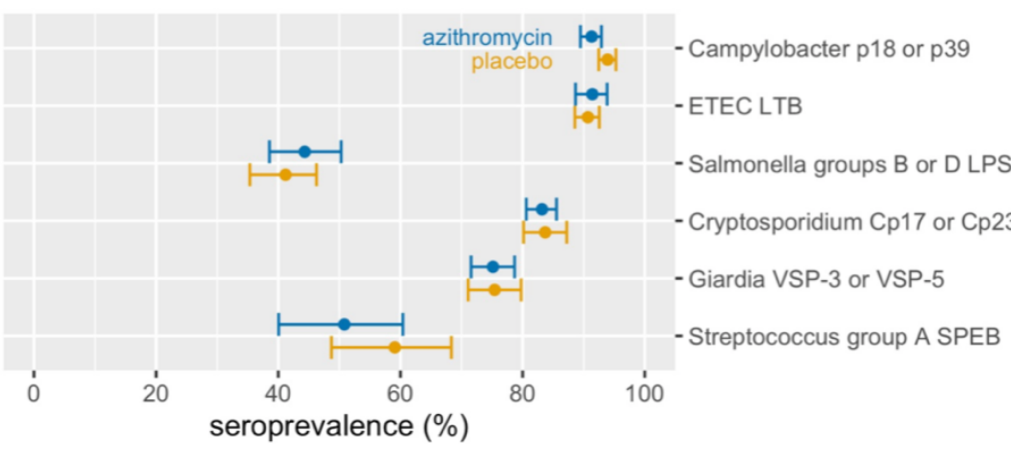

D

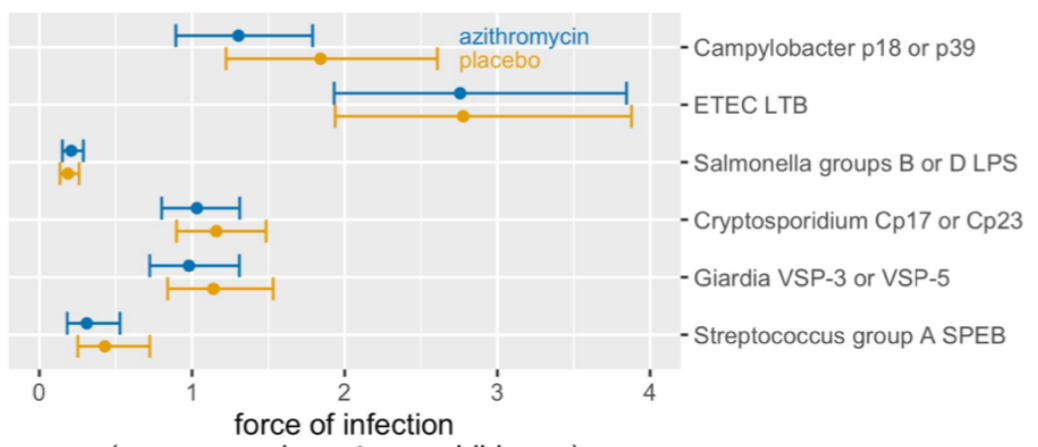

(seroconversion rate per child-year)
$\mathrm{B}$
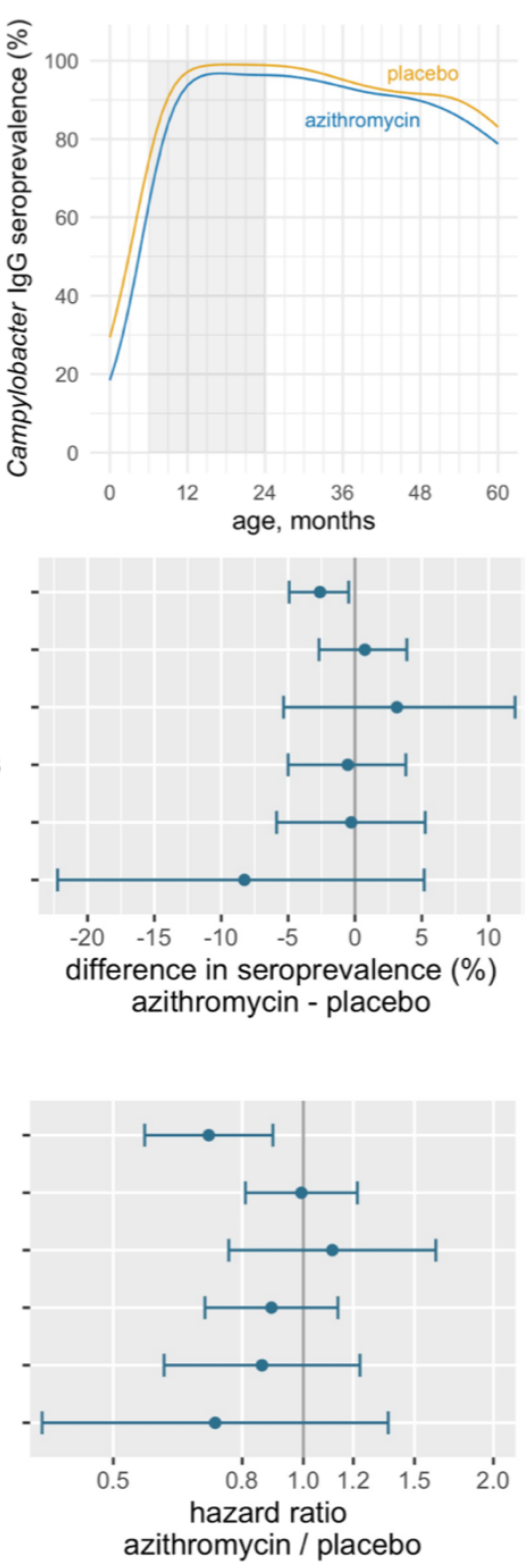

Figure 3. Bacterial and protozoan IgG antibody responses among preschool aged children in the MORDOR Niger trial, 2015-2018. (A) Community-level seroprevalence to malarial antigens. Columns represent individual communities, which were stratified by treatment group and then sorted by overall mean seroprevalence. (B) Seroprevalence to Campylobacter spp. p18 or p39 antigens by age and treatment arm, estimated with semiparametric splines. The shaded region from 6-24 months indicates the age range included in the force of infection analyses, based on a pre-specified rule. (C) Pathogenspecific IgG seroprevalence by treatment arm and difference between arms. (D). Pathogen-specific force of infection estimated by the seroconversion rate, and hazard ratio for comparison between arms. The reduction in Campylobacter spp. transmission remained statistically significant after FDR correction. Created with notebooks https://osf.io/b2v3r, https://osf.io/smwbn, https://osf.io/fwxn5, which include detailed point estimates and additional, consistent results based on geometric mean IgG levels. 
medRxiv preprint doi: https://doi.org/10.1101/2021.04.23.21255957; this version posted April 26, 2021. The copyright holder for this preprint (which was not certified by peer review) is the author/funder, who has granted medRxiv a license to display the preprint in perpetuity. This article is a US Government work. It is not subject to copyright under 17 USC 105 and is also made available for use under a CCO license.

\section{Effect of biannual azithromycin distribution on antibody responses to malaria, bacterial, and protozoan pathogens among children: A cluster-randomized, placebo-controlled trial in Niger}

Ahmed M. Arzika, Ramatou Maliki, E. Brook Goodhew, Eric Rogier, Jeffrey W. Priest, Elodie Lebas, Kieran S. O'Brien, Victoria Le, Catherine E. Oldenburg, Thuy Doan, Travis C. Porco, Jeremy D. Keenan, Thomas M. Lietman, Diana L. Martin, Benjamin F. Arnold, for the MORDOR-Niger Study Group

\section{Supplementary Information Materials}


medRxiv preprint doi: https://doi.org/10.1101/2021.04.23.21255957; this version posted April 26, 2021. The copyright holder for this preprint (which was not certified by peer review) is the author/funder, who has granted medRxiv a license to display the preprint in perpetuity.

This article is a US Government work. It is not subject to copyright under 17 USC 105 and is also made available for use under a CCO license.

A

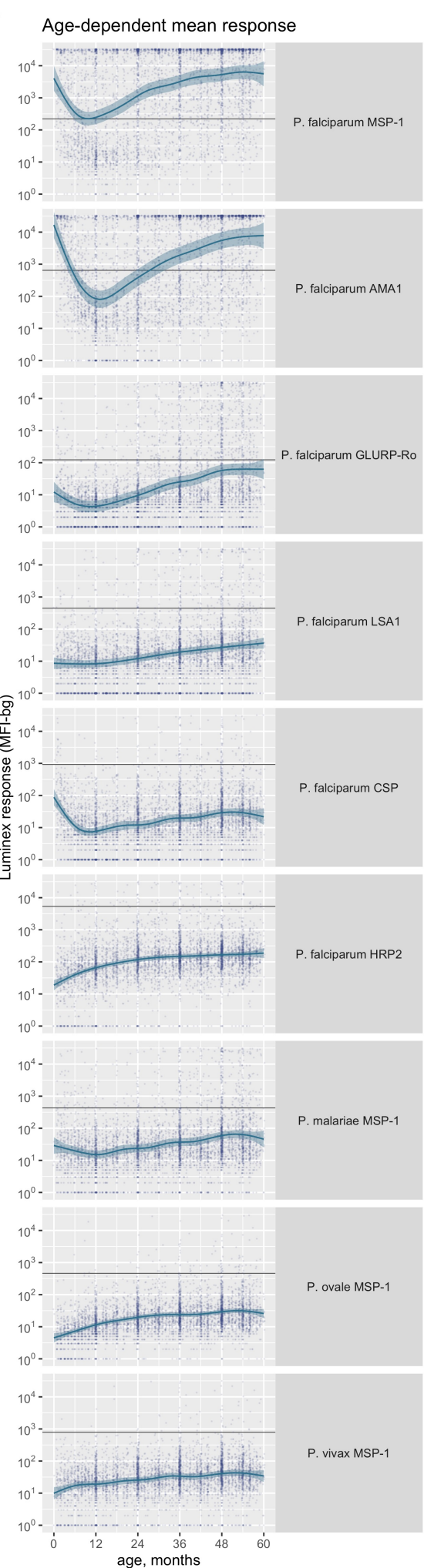

$B$
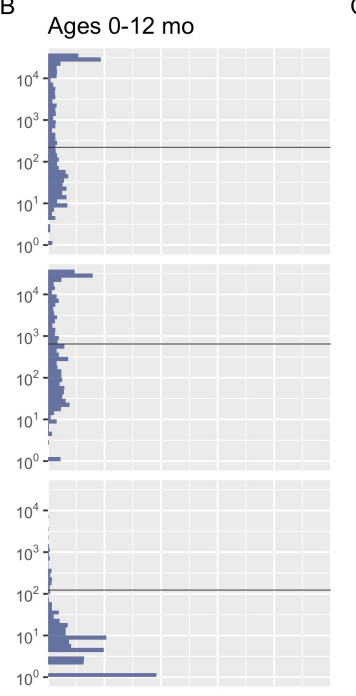

$10^{4}-$

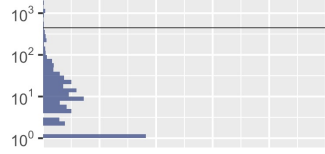

$10^{4}$

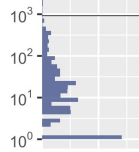

$10^{4}-$

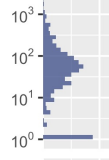

$10^{4}$

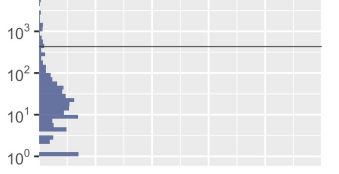

$10^{4}-$

$10^{3}-$

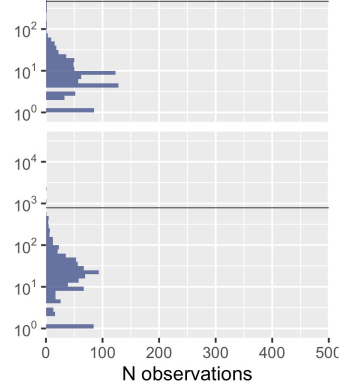

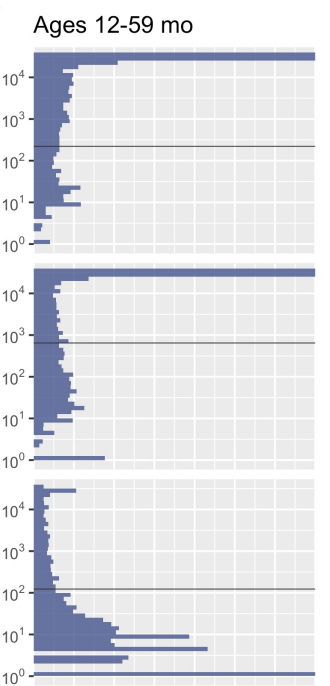
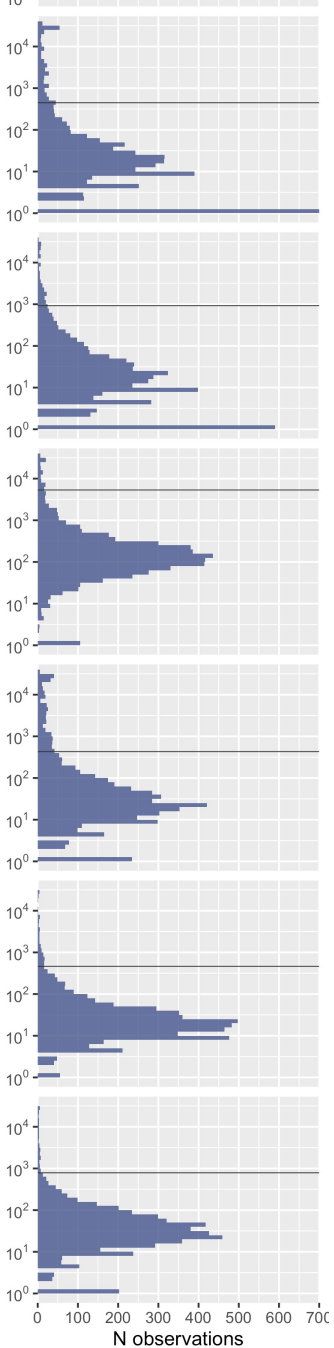

SI Figure 1. Malarial antibody responses among children ages 0-59 months in MORDOR Niger. (A) Age dependent mean response estimated with cubic splines, shaded bands are simultaneous $95 \%$ confidence intervals. Distribution of antibody response among children ages 0-12 months (B), and ages 12.1 to 59 months (C). Horizontal lines mark the seropositivity cutoffs derived from panels of negative sera. Created with notebook https://osf.io/vatbm. 
medRxiv preprint doi: https://doi.org/10.1101/2021.04.23.21255957; this version posted April 26, 2021. The copyright holder for this preprint (which was not certified by peer review) is the author/funder, who has granted medRxiv a license to display the preprint in perpetuity.

This article is a US Government work. It is not subject to copyright under 17 USC 105 and is also made available for use under a CCO license.
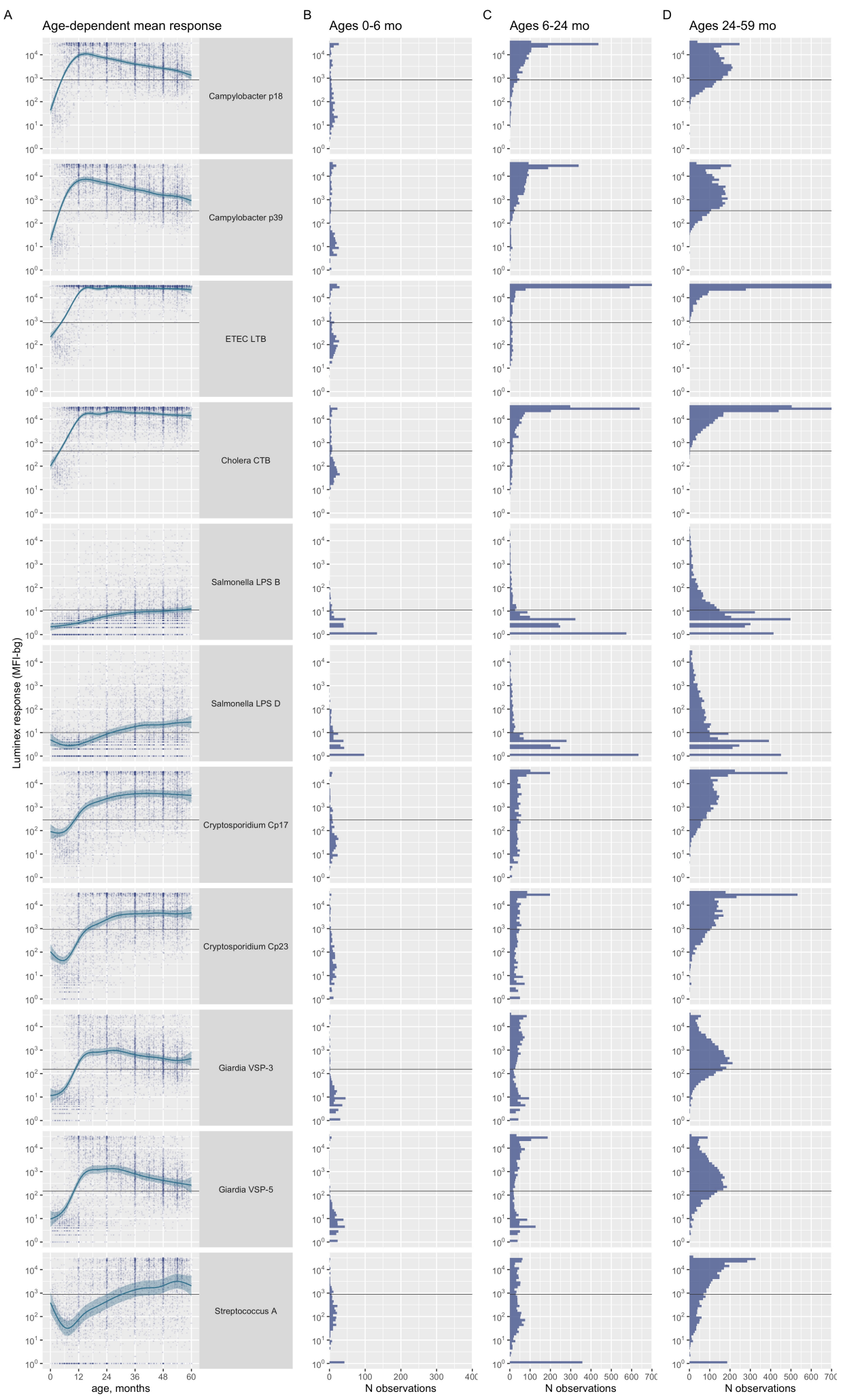

SI Figure 2. Antibody responses to bacteria and protozoan pathogens among children ages 0-59 months in MORDOR Niger. (A) Age dependent mean response estimated with cubic splines, shaded bands are simultaneous $95 \%$ confidence intervals. Distribution of antibody response among children ages 0-6 months (B), ages 6.1 to 24 months (C), and 24.1 to 59 months (D). Horizontal lines mark the seropositivity cutoffs derived through ROC curves (Cryptosporidium sp., Giardia sp.) or using the mean plus 3xSD among presumed unexposed children (others, described in Methods). Created with notebook https://osf.io/vqtbm. 
medRxiv preprint doi: https://doi.org/10.1101/2021.04.23.21255957; this version posted April 26, 2021. The copyright holder for this preprint (which was not certified by peer review) is the author/funder, who has granted medRxiv a license to display the preprint in perpetuity.

This article is a US Government work. It is not subject to copyright under 17 USC 105 and is also made available for use under a CCO license.

A

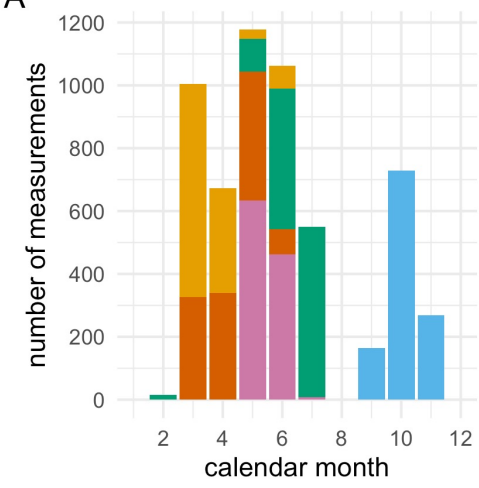

B

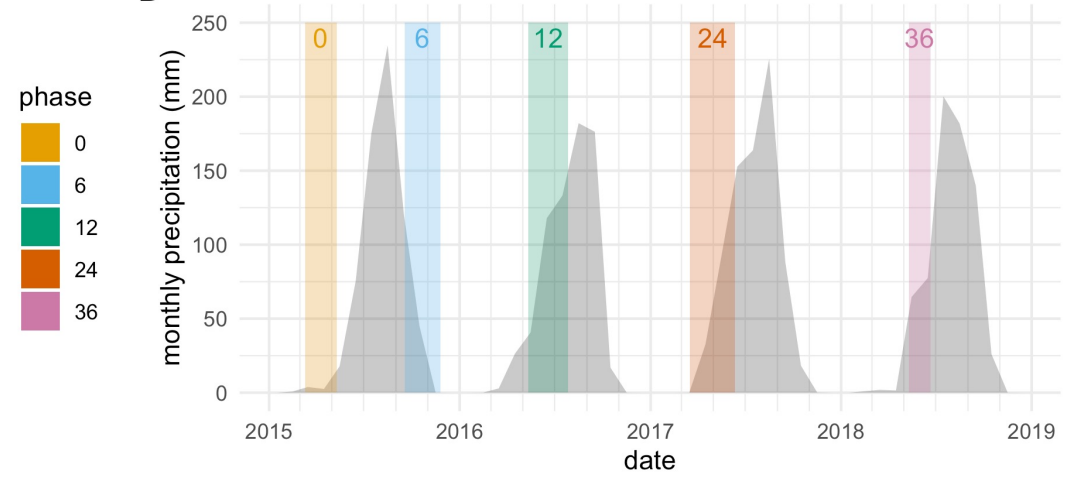

SI Figure 3. Dried blood spot measurement timing and monthly rainfall in the MORDOR Niger trial. (A) Specimens collected by calendar month and study phase (months since baseline). (B) Monthly precipitation in study communities. Colored shading indicates timing of dried blood spot specimen collection for each study phase. Created with notebook https://osf.io/pem3z . 
medRxiv preprint doi: https://doi.org/10.1101/2021.04.23.21255957; this version posted April 26, 2021. The copyright holder for this preprint (which was not certified by peer review) is the author/funder, who has granted medRxiv a license to display the preprint in perpetuity.

This article is a US Government work. It is not subject to copyright under 17 USC 105 and is also made available for use under a CCO license.

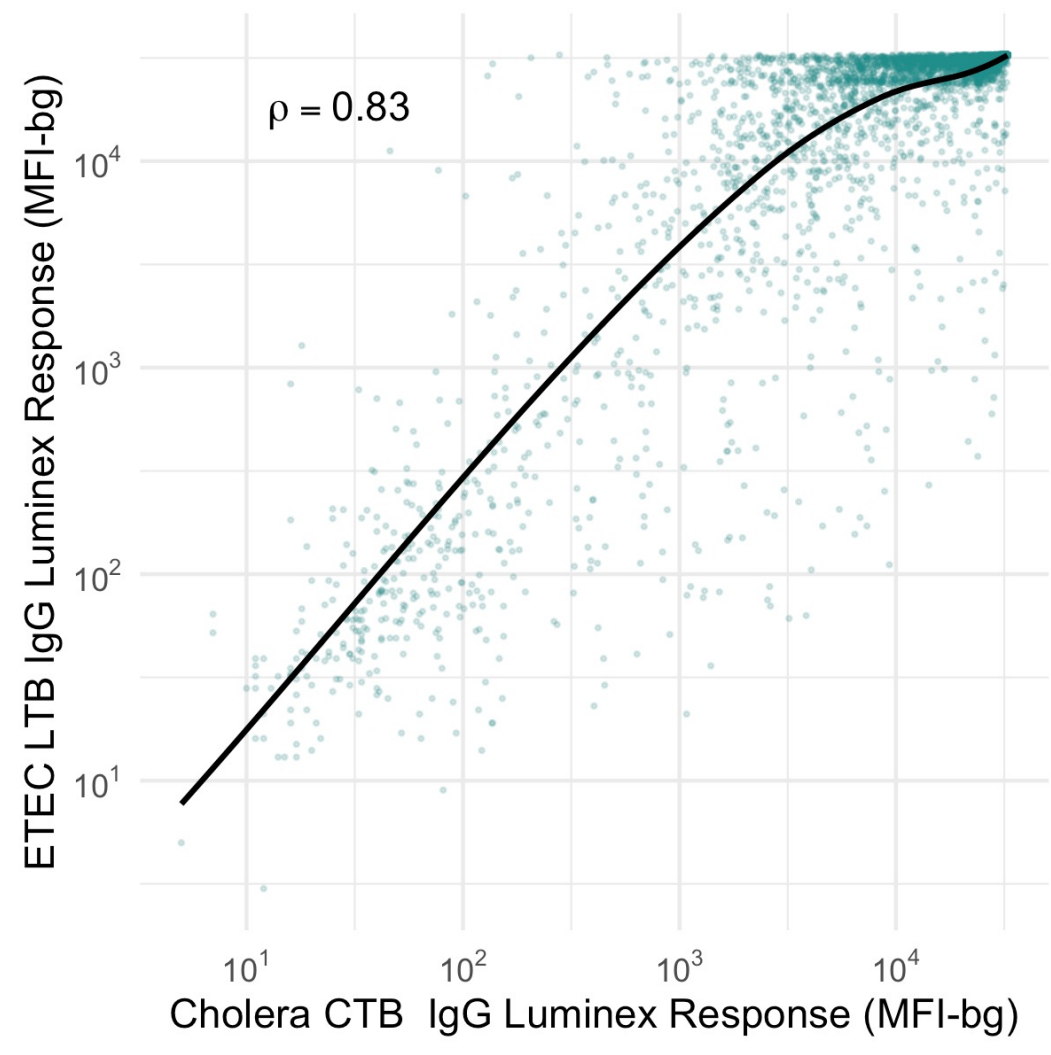

SI Figure 4. Correlation between antibody responses to enterotoxigenic E. coli labile toxin B subunit (ETEC LTB) and V. cholera toxin B subunit (cholera CTB) among children ages 6-59 months in Niger. Spearman rank correlation $(\rho)$ estimated from 5,642 measurements (points). Solid line is a locally weighted smooth. Created with notebook https://osf.io/5vs7r. 
medRxiv preprint doi: https://doi.org/10.1101/2021.04.23.21255957; this version posted April 26, 2021. The copyright holder for this preprint (which was not certified by peer review) is the author/funder, who has granted medRxiv a license to display the preprint in perpetuity.

This article is a US Government work. It is not subject to copyright under 17 USC 105 and is also made available for use under a CCO license.

SI Figure 5. Malarial IgG antibody response among preschool aged children in the MORDOR Niger trial by treatment group and age, 2015-2018. (A) Mean IgG responses (MFI-bg) (B) Seroprevalence. Shaded area indicates age range included in analyses (1259 months). Group means estimated using semiparametric cubic splines. Shaded bands are simultaneous 95\% confidence intervals. Created with notebook https://osf.io/smwbn .
A
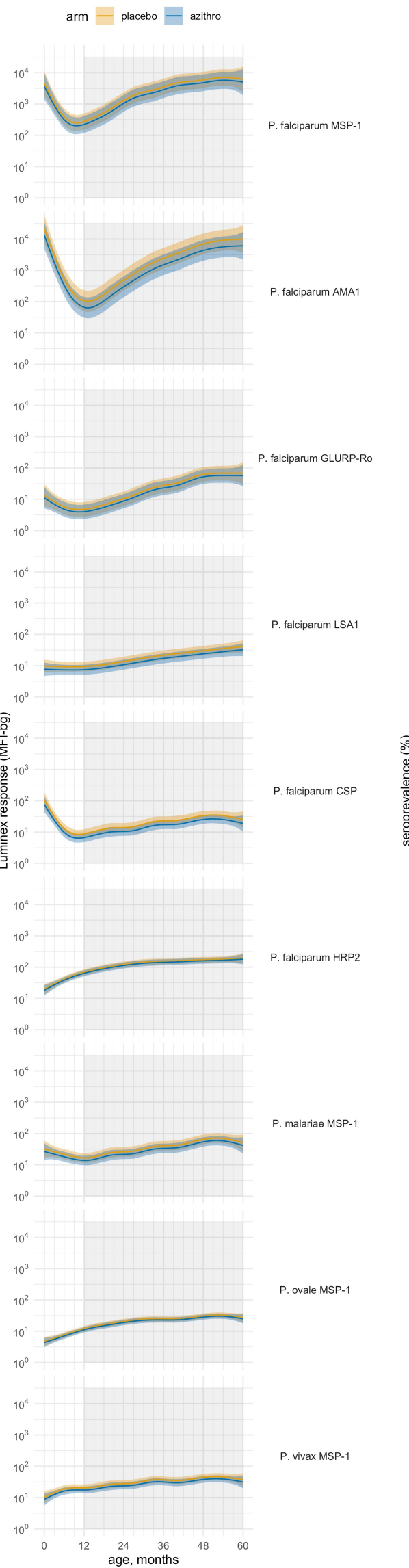

B

arm $=$ placebo - azithro
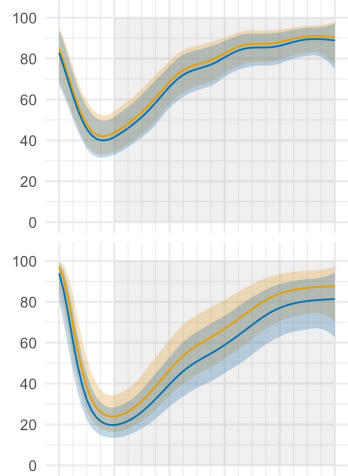

100

60

40

0

80

60

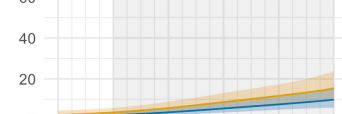

P. falciparum HRP2

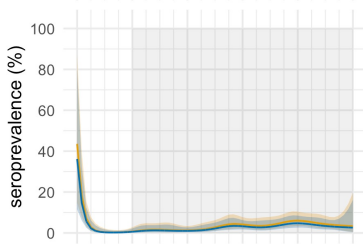

P. malariae MSP-1

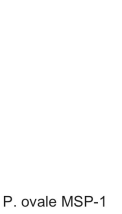

P. ovale MSP-1

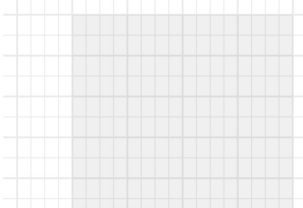

P. vivax MSP-1

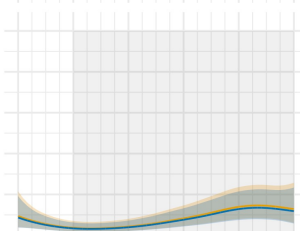

100

80

80

40

40

0

P.

100

80

80
60

40

20

$12 \begin{array}{cccc}24 & 36 & 48 \quad 60 \\ \text { age, months } & & \end{array}$ 
medRxiv preprint doi: https://doi.org/10.1101/2021.04.23.21255957; this version posted April 26, 2021. The copyright holder for this preprint (which was not certified by peer review) is the author/funder, who has granted medRxiv a license to display the preprint in perpetuity.

This article is a US Government work. It is not subject to copyright under 17 USC 105 and is also made available for use under a CCO license.
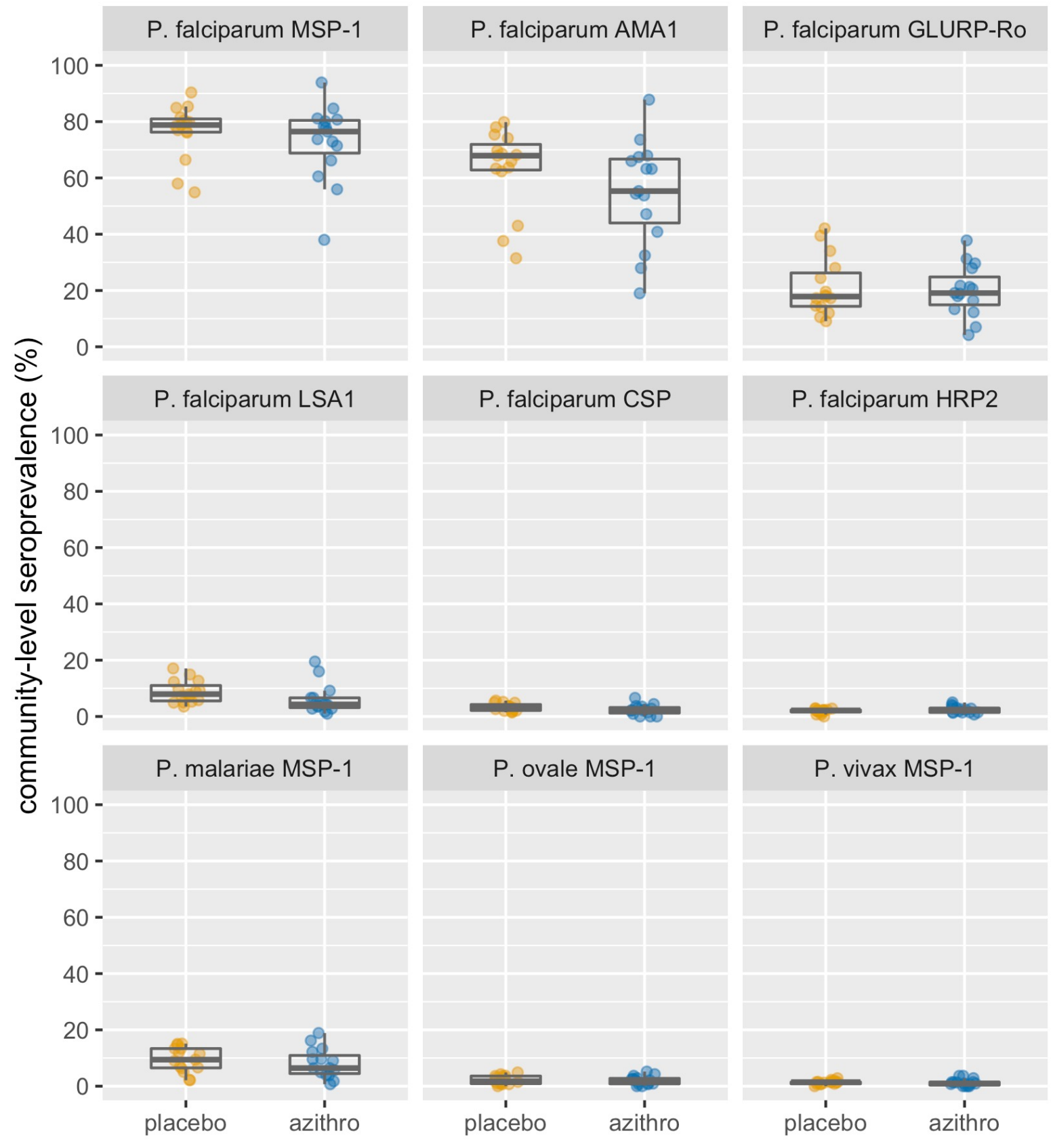

\section{P. vivax MSP-1}

SI Figure 6. Community level IgG seroprevalence for malarial antigens among preschool aged children in the MORDOR Niger trial by treatment group, 2015-2018. Box plots show the median and interquartile range for the 15 communities in each group. Created with notebook https://osf.io/b2v3r. 
medRxiv preprint doi: https://doi.org/10.1101/2021.04.23.21255957; this version posted April 26, 2021. The copyright holder for this preprint (which was not certified by peer review) is the author/funder, who has granted medRxiv a license to display the preprint in perpetuity.

This article is a US Government work. It is not subject to copyright under 17 USC 105 and is also made available for use under a CCO license.

A

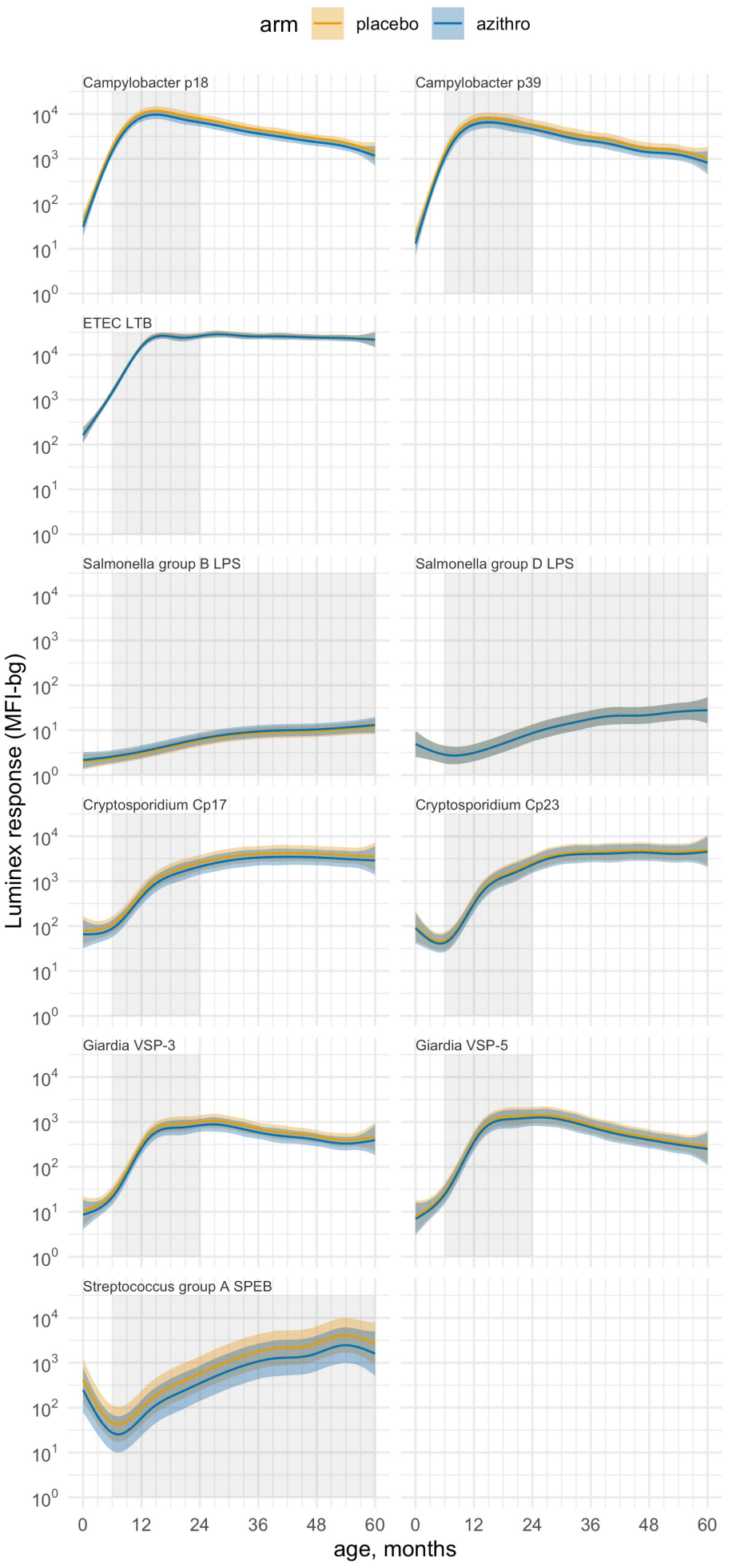

B

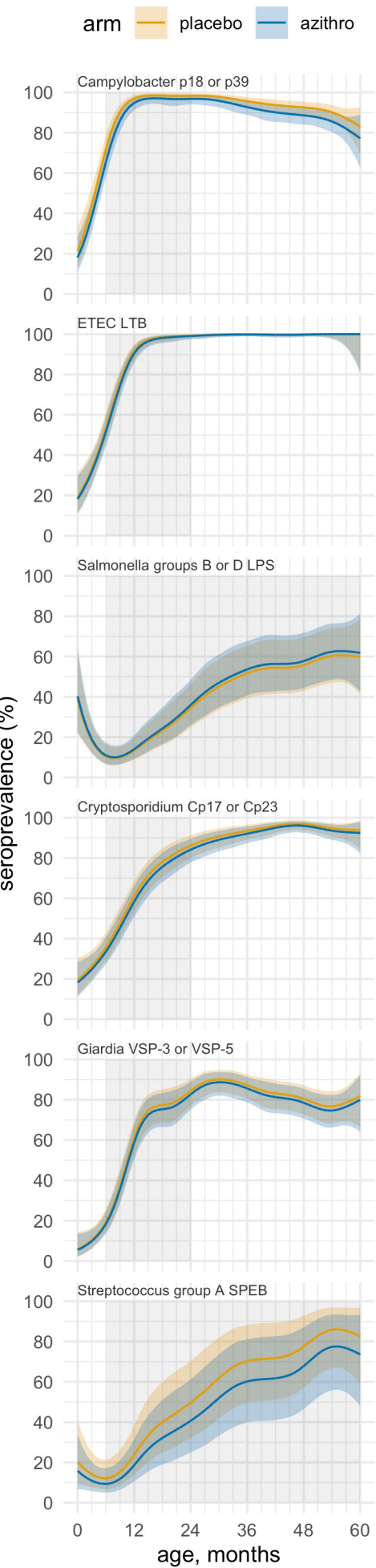

SI Figure 7. IgG antibody responses to bacterial and protozoan pathogens among preschool aged children in the MORDOR Niger trial by treatment group and age, 2015-2018. (A) Mean IgG responses (MFI-bg). (B) Seroprevalence. Shaded area indicates age range included in force of infection analyses. Group means estimated using semiparametric cubic splines. Shaded bands are simultaneous $95 \%$ confidence intervals. Created with notebook https://osf.io/smwbn . 
medRxiv preprint doi: https://doi.org/10.1101/2021.04.23.21255957; this version posted April 26, 2021. The copyright holder for this preprint (which was not certified by peer review) is the author/funder, who has granted medRxiv a license to display the preprint in perpetuity.

This article is a US Government work. It is not subject to copyright under 17 USC 105 and is also made available for use under a CCO license.

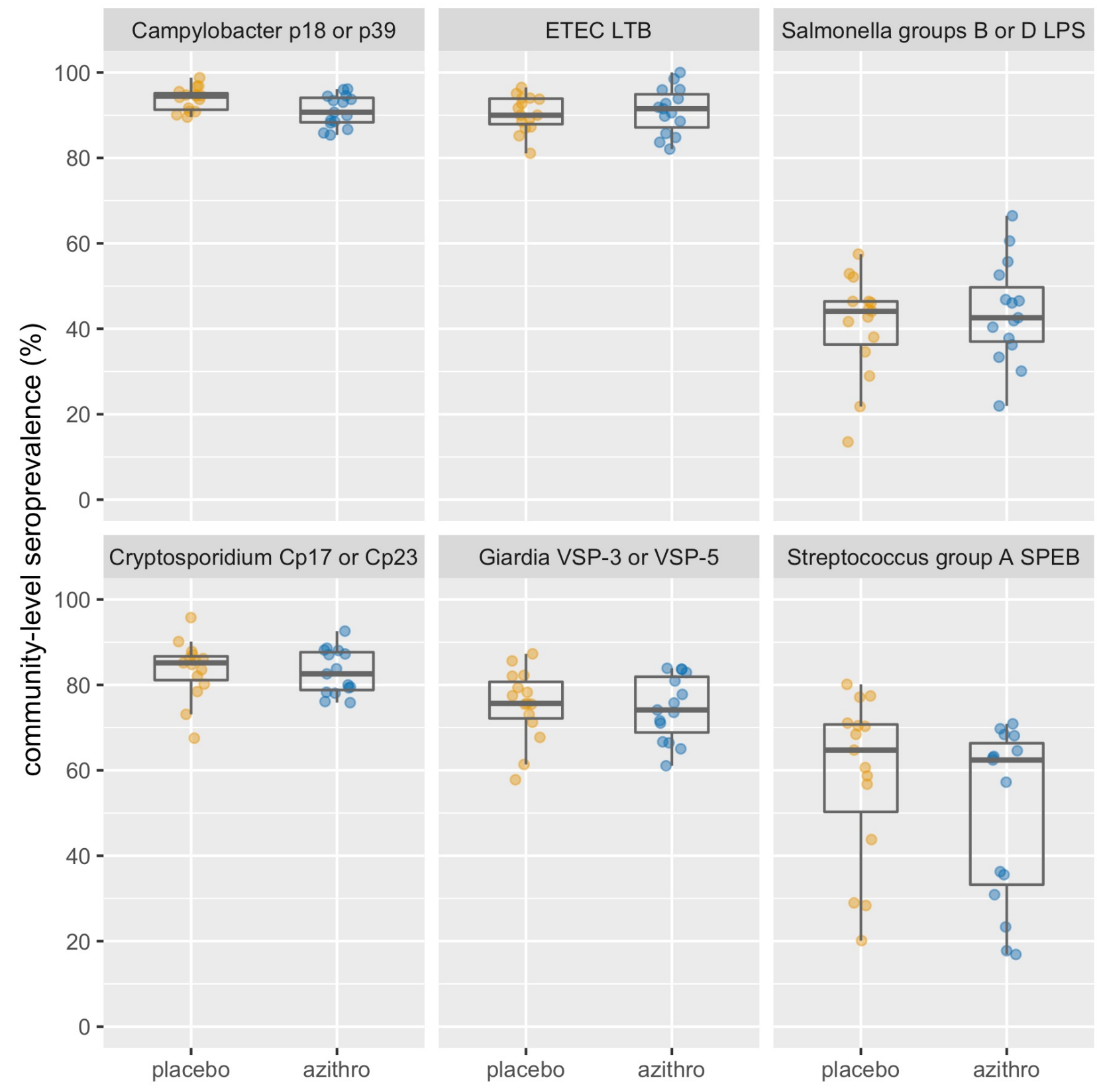

SI Figure 8. Community level IgG seroprevalence for bacteria and protozoan pathogens among preschool aged children in the MORDOR Niger trial by treatment group, 2015-2018. Box plots show the median and interquartile range for the 15 communities in each group. Created with notebook https://osf.io/b2v3r. 
medRxiv preprint doi: https://doi.org/10.1101/2021.04.23.21255957; this version posted April 26, 2021. The copyright holder for this preprint (which was not certified by peer review) is the author/funder, who has granted medRxiv a license to display the preprint in perpetuity.

This article is a US Government work. It is not subject to copyright under 17 USC 105 and is also made available for use under a CCO license.

A

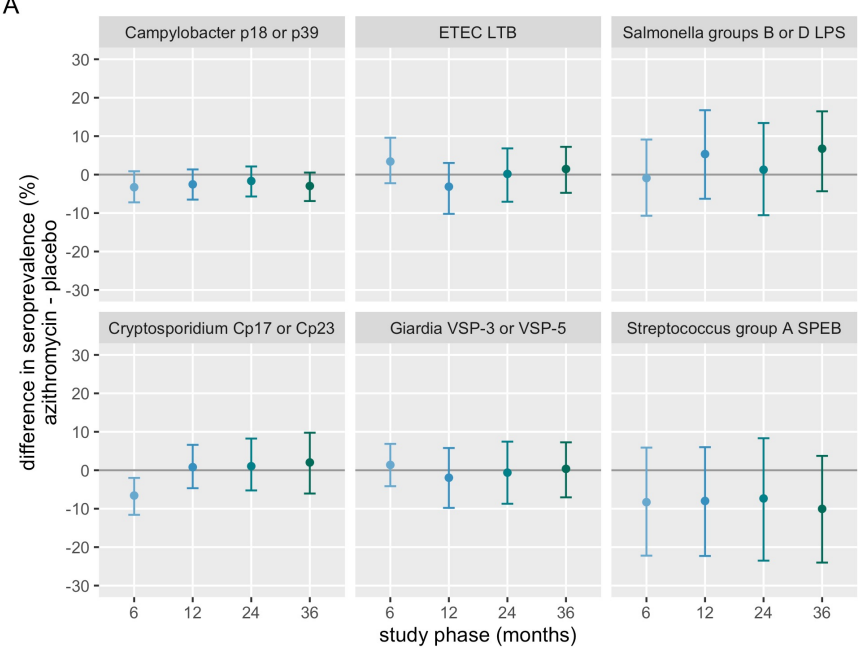

B

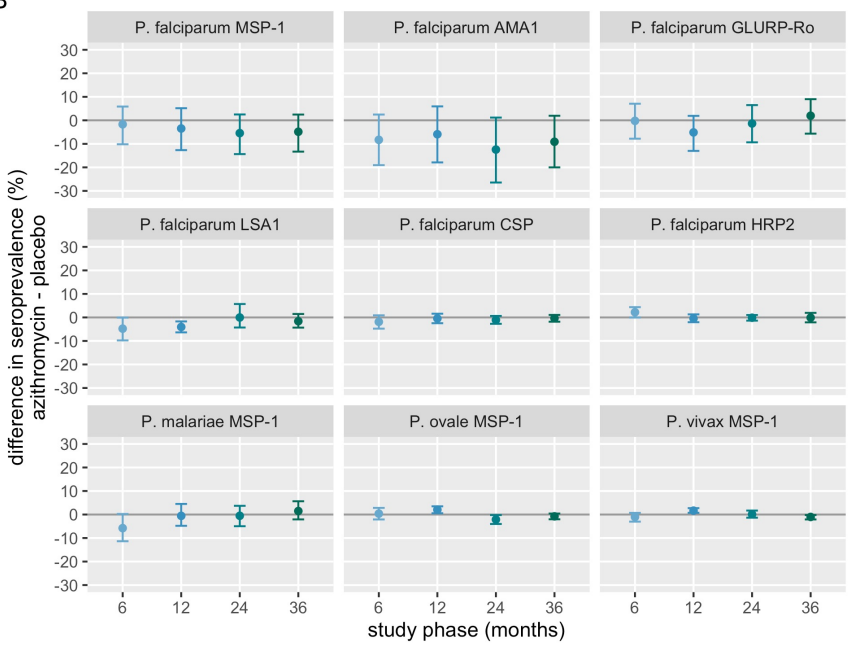

SI Figure 9. Difference in seroprevalence between intervention groups for bacterial and protozoan pathogens and malaria among children under age five years in MORDOR Niger, 2015-2018, stratified by study phase (months since baseline). (A) Bacteria and protozoan antibody responses. (B) Malaria antibody responses. There was no evidence for additive effect modification by study phase. Created with notebook https://osf.io/w2rvp, which includes additional details including formal tests of additive effect modification. 
medRxiv preprint doi: https://doi.org/10.1101/2021.04.23.21255957; this version posted April 26, 2021. The copyright holder for this preprint (which was not certified by peer review) is the author/funder, who has granted medRxiv a license to display the preprint in perpetuity.

This article is a US Government work. It is not subject to copyright under 17 USC 105 and is also made available for use under a CCO license.

A

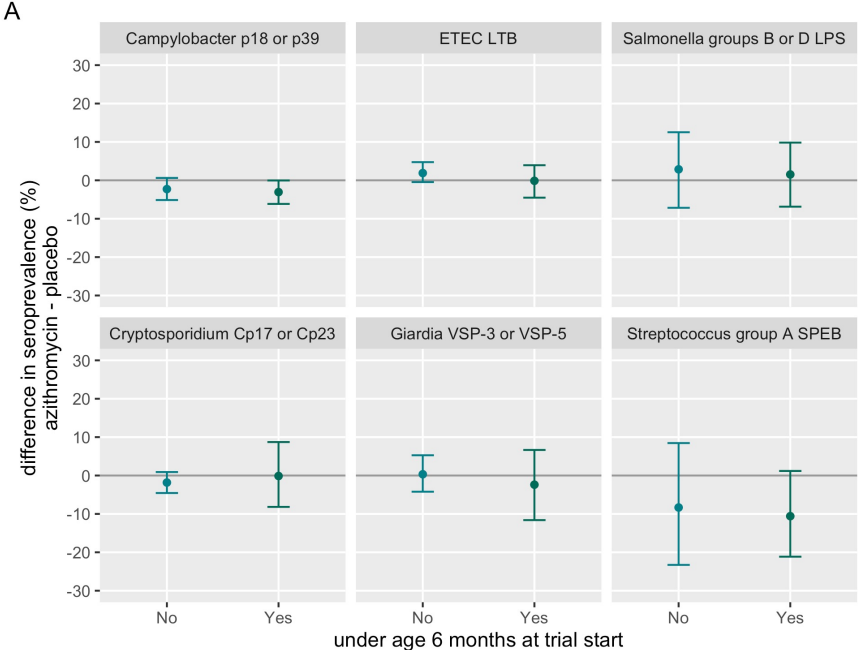

B

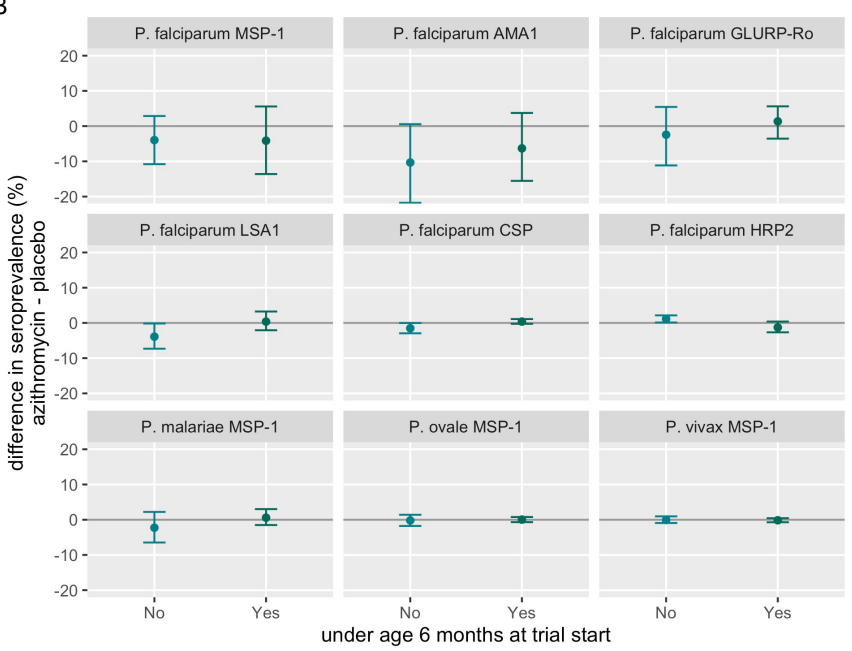

SI Figure 10. Difference in seroprevalence between intervention groups for bacterial and protozoan pathogens and malaria among children under age five years in MORDOR Niger, 2015-2018, stratified by child age at the start of the trial. (A) Bacterial and protozoan antibody responses. (B) Malaria antibody responses. There was no evidence for additive effect modification by child age. Created with notebook https://osf.io/w2rvp, which includes additional details including formal tests of additive effect modification. 
medRxiv preprint doi: https://doi.org/10.1101/2021.04.23.21255957; this version posted April 26, 2021. The copyright holder for this preprint (which was not certified by peer review) is the author/funder, who has granted medRxiv a license to display the preprint in perpetuity.

This article is a US Government work. It is not subject to copyright under 17 USC 105 and is also made available for use under a CCO license.

SI Table 1. Seroconversion rates for malaria, bacterial, and protozoan pathogens estimated in longitudinal analyses of children under age five years in MORDOR Niger, 2015-2018.

Seroconversion was defined as transition from seronegative to seropositive status. IRR: incidence rate ratio for azithromycin / placebo seroconversion rates. Created with notebook https://osf.io/9875t.

\begin{tabular}{|c|c|c|c|c|c|c|c|}
\hline \multirow[b]{2}{*}{ Pathogen, antigen } & \multicolumn{3}{|c|}{ Azithromycin } & \multicolumn{3}{|c|}{ Placebo } & \multirow[b]{2}{*}{ IRR (95\% Cl) } \\
\hline & $\begin{array}{r}\mathrm{N} \\
\text { events }\end{array}$ & $\begin{array}{r}\text { Person- } \\
\text { Years }\end{array}$ & $\begin{array}{c}\text { Rate per year }(95 \% \\
\text { Cl) }\end{array}$ & $\begin{array}{r}\mathbf{N} \\
\text { events }\end{array}$ & $\begin{array}{r}\text { Person- } \\
\text { Years }\end{array}$ & $\begin{array}{c}\text { Rate per year }(95 \% \\
\text { Cl) }\end{array}$ & \\
\hline \multicolumn{8}{|l|}{ Malaria } \\
\hline $\begin{array}{l}\text { P. falciparum } \\
\text { MSP-1 }\end{array}$ & 88 & 173.58 & $0.51(0.41,0.64)$ & 76 & 107.04 & $0.71(0.46,1.02)$ & $0.71(0.48,1.16)$ \\
\hline $\begin{array}{l}\text { P. falciparum } \\
\text { AMA1 }\end{array}$ & 94 & 345.75 & $0.27(0.19,0.38)$ & 106 & 192.96 & $0.55(0.41,0.76)$ & $0.49(0.31,0.76)$ \\
\hline $\begin{array}{l}\text { P. falciparum } \\
\text { GLURP-Ro }\end{array}$ & 69 & 606.92 & $0.11(0.08,0.15)$ & 73 & 469.96 & $0.16(0.11,0.22)$ & $0.73(0.44,1.13)$ \\
\hline $\begin{array}{l}\text { P. falciparum } \\
\text { LSA1 }\end{array}$ & 18 & 684.29 & $0.03(0.01,0.06)$ & 25 & 567.88 & $0.04(0.02,0.07)$ & $0.60(0.15,1.50)$ \\
\hline $\begin{array}{l}\text { P. falciparum } \\
\text { CSP }\end{array}$ & 9 & 722.33 & $0.01(0.00,0.02)$ & 14 & 588.29 & $0.02(0.01,0.04)$ & $0.52(0.19,1.14)$ \\
\hline $\begin{array}{l}\text { P. falciparum } \\
\text { HRP2 }\end{array}$ & 13 & 720.21 & $0.02(0.01,0.03)$ & 9 & 596.46 & $0.02(0.01,0.02)$ & $1.20(0.47,3.60)$ \\
\hline $\begin{array}{l}\text { P. malariae } \\
\text { MSP-1 }\end{array}$ & 34 & 676.12 & $0.05(0.02,0.08)$ & 30 & 563.88 & $0.05(0.03,0.07)$ & $0.95(0.43,1.77)$ \\
\hline P. ovale MSP-1 & 13 & 723.12 & $0.02(0.01,0.03)$ & 11 & 602.21 & $0.02(0.01,0.03)$ & $0.98(0.38,2.43)$ \\
\hline P. vivax MSP-1 & 4 & 723.46 & $0.01(0.00,0.01)$ & 9 & 604.00 & $0.01(0.01,0.02)$ & $0.37(0.00,1.07)$ \\
\hline \multicolumn{8}{|l|}{ Bacteria \& protozoa } \\
\hline $\begin{array}{l}\text { Campylobacter } \\
\text { p18 or p39 }\end{array}$ & 63 & 29.21 & $2.16(1.85,2.51)$ & 34 & 12.79 & $2.66(2.18,3.25)$ & $0.81(0.62,1.04)$ \\
\hline ETEC LTB & 69 & 33.71 & $2.05(1.68,2.57)$ & 51 & 22.67 & $2.25(1.85,2.59)$ & $0.91(0.71,1.22)$ \\
\hline $\begin{array}{l}\text { Salmonella } \\
\text { groups B or D } \\
\text { LPS }\end{array}$ & 162 & 432.21 & $0.37(0.28,0.50)$ & 121 & 403.54 & $0.30(0.21,0.39)$ & $1.25(0.81,1.94)$ \\
\hline $\begin{array}{l}\text { Cryptosporidium } \\
\text { Cp17 or Cp23 }\end{array}$ & 80 & 63.42 & $1.26(0.98,1.54)$ & 53 & 45.67 & $1.16(0.83,1.47)$ & $1.09(0.76,1.57)$ \\
\hline $\begin{array}{l}\text { Giardia VSP-3 or } \\
\text { VSP-5 }\end{array}$ & 87 & 81.50 & $1.07(0.81,1.36)$ & 53 & 53.04 & $1.00(0.77,1.28)$ & $1.07(0.74,1.54)$ \\
\hline $\begin{array}{l}\text { Streptococcus } \\
\text { group A SPEB }\end{array}$ & 140 & 367.58 & $0.38(0.22,0.59)$ & 120 & 288.12 & $0.42(0.29,0.61)$ & $0.91(0.45,1.59)$ \\
\hline
\end{tabular}


medRxiv preprint doi: https://doi.org/10.1101/2021.04.23.21255957; this version posted April 26, 2021. The copyright holder for this preprint (which was not certified by peer review) is the author/funder, who has granted medRxiv a license to display the preprint in perpetuity.

This article is a US Government work. It is not subject to copyright under 17 USC 105 and is also made available for use under a CCO license.

SI Table 2. Seroreversion rates for malaria, bacterial, and protozoan pathogens estimated in longitudinal analyses of preschool children in MORDOR Niger, 2015-2018. Seroreversion was defined as a transition from seropositive to seronegative status. IRR: incidence rate ratio for azithromycin / placebo seroreversion rates. The IRR was not estimated for ETEC LTB because there were no events in the placebo group. Created with notebook https://osf.io/9875t.

\begin{tabular}{|c|c|c|c|c|c|c|c|}
\hline \multirow[b]{2}{*}{ Pathogen, antigen } & \multicolumn{3}{|c|}{ Azithromycin } & \multicolumn{3}{|c|}{ Placebo } & \multirow[b]{2}{*}{ IRR (95\% Cl) } \\
\hline & $\begin{array}{r}\mathbf{N} \\
\text { events }\end{array}$ & $\begin{array}{r}\text { Person- } \\
\text { Years }\end{array}$ & $\begin{array}{c}\text { Rate per year }(95 \% \\
\mathrm{Cl})\end{array}$ & $\begin{array}{r}\mathbf{N} \\
\text { events }\end{array}$ & $\begin{array}{r}\text { Person- } \\
\text { Years }\end{array}$ & $\begin{array}{c}\text { Rate per year }(95 \% \\
\text { Cl) }\end{array}$ & \\
\hline \multicolumn{8}{|l|}{ Malaria } \\
\hline $\begin{array}{l}\text { P. falciparum } \\
\text { MSP-1 }\end{array}$ & 42 & 493.04 & $0.09(0.06,0.11)$ & 35 & 439.25 & $0.08(0.05,0.11)$ & $1.07(0.65,1.80)$ \\
\hline $\begin{array}{l}\text { P. falciparum } \\
\text { AMA1 }\end{array}$ & 35 & 320.71 & $0.11(0.07,0.17)$ & 38 & 336.12 & $0.11(0.08,0.16)$ & $0.97(0.55,1.67)$ \\
\hline $\begin{array}{l}\text { P. falciparum } \\
\text { GLURP-Ro }\end{array}$ & 34 & 81.58 & $0.42(0.29,0.60)$ & 28 & 87.71 & $0.32(0.21,0.46)$ & $1.31(0.77,2.19)$ \\
\hline $\begin{array}{l}\text { P. falciparum } \\
\text { LSA1 }\end{array}$ & 20 & 38.25 & $0.52(0.36,0.91)$ & 21 & 22.92 & $0.92(0.67,1.24)$ & $0.57(0.36,1.05)$ \\
\hline $\begin{array}{l}\text { P. falciparum } \\
\text { CSP }\end{array}$ & 12 & 9.79 & $1.23(0.77,1.58)$ & 14 & 10.92 & $1.28(0.86,1.80)$ & $0.96(0.51,1.59)$ \\
\hline $\begin{array}{l}\text { P. falciparum } \\
\text { HRP2 }\end{array}$ & 12 & 9.75 & $1.23(0.60,1.85)$ & 12 & 6.00 & $2.00(1.29,3.47)$ & $0.62(0.27,1.15)$ \\
\hline $\begin{array}{l}\text { P. malariae } \\
\text { MSP-1 }\end{array}$ & 25 & 38.58 & $0.65(0.40,1.08)$ & 25 & 21.62 & $1.16(0.67,1.66)$ & $0.56(0.30,1.16)$ \\
\hline P. ovale MSP-1 & 15 & 8.08 & $1.86(1.13,2.79)$ & 2 & 2.58 & $0.77(0.00,1.20)$ & $2.40(1.21,4.84)$ \\
\hline P. vivax MSP-1 & 13 & 9.96 & $1.31(0.88,1.87)$ & 3 & 2.21 & $1.36(1.20,1.60)$ & $0.96(0.64,1.40)$ \\
\hline \multicolumn{8}{|l|}{ Bacteria \& protozoa } \\
\hline $\begin{array}{l}\text { Campylobacter } \\
\text { p18 or p39 }\end{array}$ & 3 & 103.62 & $0.03(0.00,0.06)$ & 1 & 93.50 & $0.01(0.00,0.04)$ & $2.71(0.00,5.33)$ \\
\hline ETEC LTB & 2 & 96.62 & $0.02(0.00,0.05)$ & 0 & 76.33 & 0 & $\mathrm{n} / \mathrm{a}$ \\
\hline $\begin{array}{l}\text { Salmonella } \\
\text { groups B or D } \\
\text { LPS }\end{array}$ & 56 & 298.50 & $0.19(0.12,0.28)$ & 40 & 209.62 & $0.19(0.14,0.27)$ & $0.98(0.54,1.66)$ \\
\hline $\begin{array}{l}\text { Cryptosporidium } \\
\text { Cp17 or Cp23 }\end{array}$ & 24 & 55.29 & $0.43(0.28,0.63)$ & 7 & 45.92 & $0.15(0.05,0.25)$ & $2.85(1.52,8.49)$ \\
\hline $\begin{array}{l}\text { Giardia VSP-3 or } \\
\text { VSP-5 }\end{array}$ & 11 & 38.92 & $0.28(0.10,0.61)$ & 2 & 44.00 & $0.05(0.00,0.13)$ & $6.22(1.33,21.06)$ \\
\hline $\begin{array}{l}\text { Streptococcus } \\
\text { group A SPEB }\end{array}$ & 55 & 388.79 & $0.14(0.11,0.21)$ & 39 & 328.25 & $0.12(0.06,0.21)$ & $1.19(0.62,2.61)$ \\
\hline
\end{tabular}

group A SPEB 
SI Table 3. Homology for Campylobacter jejuni p18 and p39 antigens.

Results from a Basic Local Alignment Search Tool for Proteins (BLASTP) analysis.

\begin{tabular}{|c|c|c|c|c|c|c|c|c|}
\hline \multirow[b]{2}{*}{ Species } & \multicolumn{4}{|c|}{ p18 (cj0113/ Omp18/ PAL) } & \multicolumn{4}{|c|}{ p39 (amino acids $188-508$ of $\mathrm{cj} 0017 \mathrm{c} / \mathrm{dsbl}$ ) } \\
\hline & Strain & Accession No. & $\begin{array}{c}\text { Identity } \\
(\%)\end{array}$ & $\begin{array}{c}\text { Similarity } \\
(\%)\end{array}$ & Strain & Accession No. & $\begin{array}{c}\text { Identity } \\
(\%)\end{array}$ & $\begin{array}{c}\text { Similarity } \\
(\%)\end{array}$ \\
\hline Campylobacter coli & PNUSAC008160 & EAH9852560 & $100^{+}$ & 100 & PNUSAC008160 & EAH9851771 & 99 & 99 \\
\hline Campylobacter lari & 2003D-6133 & EAI4455352 & $100^{+}$ & 100 & PNUSAC009717 & EBF6097769 & 100 & 100 \\
\hline Campylobacter upsaliensis & AG20-0002 & EDP7905829 & $88^{+}$ & 94 & PNUSAC003222 & EAJ2130115 & 80 & 89 \\
\hline Campylobacter fetus & PNUSAC002822 & EAK5660503 & $94^{+}$ & 98 & PNUSAC008973 & EAI3655429 & 99 & 99 \\
\hline Campylobacter hyointestinalis & PNUSAC003488 & EAK5450665 & $100^{+}$ & 100 & PNUSAC002793 & EAI7421273 & 92 & 95 \\
\hline Campylobacter helveticus & & WP_082199026 & $88^{+}$ & 93 & & WP_131937627 & 79 & 88 \\
\hline Campylobacter rectus & & WP_124851039 & $56^{+}$ & 72 & & WP_004319693 & 71 & 83 \\
\hline Campylobacter mucosalis & & WP_169764118 & $55^{\mathrm{w}}$ & 77 & & WP_171993456 & 64 & 77 \\
\hline Campylobacter sputorum & & WP_033916677 & $56^{w}$ & 73 & & WP_089182023 & 62 & 77 \\
\hline Helicobacter pylori & & WP_140528957 & $33^{\text {nr }}$ & 53 & & WP_126442681 & 32 & 53 \\
\hline Haemophilus influenzae & & WP_061720771 & $36^{\mathrm{nr}}$ & 51 & & Not found & & \\
\hline Escherichia coli & NCTC13353 & SQB78611 & 36 & 53 & & Not found & & \\
\hline Salmonella enterica & serovar Eastbourne & EBS5740044 & 37 & 56 & & Not found* & & \\
\hline
\end{tabular}

Table Footnotes:

Results from Burnens, A., Stucki, U., Nicolet, J. \& Frey, J. Identification and characterization of an immunogenic outer membrane protein of Campylobacter jejuni. J. Clin. Microbiol. 33, 2826-2832 (1995)

+ Cross-reactive with C. jejuni antibody

${ }^{w}$ Weakly cross-reactive with $\mathrm{C}$. jejuni antibody

${ }^{\mathrm{nr}}$ Non-reactive with $\mathrm{C}$. jejuni antibody

*Amino acids 1-187 of the dsbl protein are present in the genome, but p39 is not 
medRxiv preprint doi: https://doi.org/10.1101/2021.04.23.21255957; this version posted April 26, 2021. The copyright holder for this preprint

(which was not certified by peer review) is the author/funder, who has granted medRxiv a license to display the preprint in perpetuity.

This article is a US Government work. It is not subject to copyright under 17 USC 105 and is also made available for use under a CCO license.

Text S1. CONSORT checklist

\begin{tabular}{|c|c|c|}
\hline Item & Description & Reported in Section \\
\hline \multicolumn{3}{|c|}{ Title and Abstract } \\
\hline $1 \mathrm{a}$ & $\begin{array}{l}\text { Identification as a randomized trial in the title; } \\
\text { Identification as a cluster randomized trial in the } \\
\text { title }\end{array}$ & Abstract \\
\hline $1 b$ & $\begin{array}{l}\text { Structured summary of trial design, methods, results, } \\
\text { and conclusions }\end{array}$ & Abstract \\
\hline \multicolumn{3}{|c|}{ Introduction } \\
\hline \multicolumn{3}{|c|}{ Background and Objectives } \\
\hline $2 a$ & $\begin{array}{l}\text { Scientific background and explanation of rationale; } \\
\text { Rationale for using a cluster design }\end{array}$ & Introduction \\
\hline $2 b$ & $\begin{array}{l}\text { Specific objectives or hypotheses; Whether } \\
\text { objectives pertain to the cluster level, the individual } \\
\text { participant level, or both }\end{array}$ & $\begin{array}{l}\text { Methods / study design and } \\
\text { participants }\end{array}$ \\
\hline \multicolumn{3}{|c|}{ Methods } \\
\hline \multicolumn{3}{|c|}{ Trial Design } \\
\hline $3 a$ & $\begin{array}{l}\text { Description of trial design (such as parallel, factorial) } \\
\text { including allocation ratio; Definition of cluster and } \\
\text { description of how the design features apply to the } \\
\text { clusters }\end{array}$ & $\begin{array}{l}\text { Methods / study design and } \\
\text { participants } \\
\text { Methods / randomization and masking }\end{array}$ \\
\hline $3 b$ & $\begin{array}{l}\text { Important changes to methods after trial } \\
\text { commencement (such as eligibility criteria), with } \\
\text { reasons }\end{array}$ & N/A \\
\hline \multicolumn{3}{|c|}{ Participants } \\
\hline $4 a$ & $\begin{array}{l}\text { Eligibility criteriafor participants; Eligibility criteria } \\
\text { for clusters }\end{array}$ & $\begin{array}{l}\text { Methods / study design and } \\
\text { participants }\end{array}$ \\
\hline $4 \mathrm{~b}$ & $\begin{array}{l}\text { Settings and locations where the data were } \\
\text { collected }\end{array}$ & $\begin{array}{l}\text { Methods / study design and } \\
\text { participants }\end{array}$ \\
\hline \multicolumn{3}{|c|}{ Interventions } \\
\hline 5 & $\begin{array}{l}\text { The interventions for each group with sufficient } \\
\text { details to allow replication, including how and when } \\
\text { they were actually administered; Whether } \\
\text { interventions pertain to the cluster level, the } \\
\text { individual participant level, or both }\end{array}$ & Methods / procedures \\
\hline
\end{tabular}


medRxiv preprint doi: https://doi.org/10.1101/2021.04.23.21255957; this version posted April 26, 2021. The copyright holder for this preprint

(which was not certified by peer review) is the author/funder, who has granted medRxiv a license to display the preprint in perpetuity.

This article is a US Government work. It is not subject to copyright under 17 USC 105 and is also made available for use under a CCO license.

\begin{tabular}{|c|c|c|}
\hline Item & Description & Reported in Section \\
\hline \multicolumn{3}{|c|}{ Outcomes } \\
\hline $6 a$ & $\begin{array}{l}\text { Completely defined pre-specified primary and } \\
\text { secondary outcome measures, including how and } \\
\text { when they were assessed; Whether outcome } \\
\text { measures pertain to the cluster level, the individual } \\
\text { participant level, orboth }\end{array}$ & Methods / outcomes \\
\hline $6 b$ & $\begin{array}{l}\text { Any changes to trial outcomes after the trial } \\
\text { commenced, with reasons }\end{array}$ & $\mathrm{N} / \mathrm{A}$ \\
\hline \multicolumn{3}{|c|}{ Sample Size } \\
\hline $7 a$ & $\begin{array}{l}\text { How sample size was determined; Method of } \\
\text { calculation, number of cluster(s) (and whether } \\
\text { equal or unequal cluster sizes are assumed), } \\
\text { cluster size, a coefficient of intracluster correlation } \\
\text { (ICC or k), and an indication of its uncertainty }\end{array}$ & $\begin{array}{l}\text { Methods / statistical analysis / statistical } \\
\text { power and detectable effects }\end{array}$ \\
\hline $7 b$ & $\begin{array}{l}\text { When applicable, explanation of any interim } \\
\text { analyses and stoppingguidelines }\end{array}$ & $\mathrm{N} / \mathrm{A}$ \\
\hline \multicolumn{3}{|c|}{ Randomization } \\
\hline \multicolumn{3}{|c|}{ Sequence Generation } \\
\hline $8 a$ & $\begin{array}{l}\text { Method used to generate the random } \\
\text { allocation sequence }\end{array}$ & Methods / Randomization and masking \\
\hline $8 b$ & $\begin{array}{l}\text { Type of randomization; details of any restriction } \\
\text { (such as blocking and block size); Details of } \\
\text { stratification or matching if used }\end{array}$ & Methods / Randomization and masking \\
\hline \multicolumn{3}{|c|}{ Allocation Concealment Mechanism } \\
\hline 9 & $\begin{array}{l}\text { Mechanism used to implement the random } \\
\text { allocation sequence (such as sequentially } \\
\text { numbered containers), describing any steps } \\
\text { taken to conceal the sequence until interventions } \\
\text { were assigned; Specification that allocation was } \\
\text { based on clusters rather than individuals and } \\
\text { whether allocation concealment (if any) was at } \\
\text { the cluster level, the individual participant level, or } \\
\text { both }\end{array}$ & Methods / Randomization and masking \\
\hline \multicolumn{3}{|c|}{ Implementation } \\
\hline $10 a$ & $\begin{array}{l}\text { Who generated the random allocation sequence, } \\
\text { who enrolled clusters, and who assigned clusters } \\
\text { to interventions }\end{array}$ & Methods / Randomization and masking \\
\hline
\end{tabular}


medRxiv preprint doi: https://doi.org/10.1101/2021.04.23.21255957; this version posted April 26, 2021. The copyright holder for this preprint

(which was not certified by peer review) is the author/funder, who has granted medRxiv a license to display the preprint in perpetuity.

This article is a US Government work. It is not subject to copyright under 17 USC 105 and is also made available for use under a CCO license.

\begin{tabular}{|c|c|c|}
\hline Item & Description & Reported in Section \\
\hline $10 \mathrm{~b}$ & $\begin{array}{l}\text { Mechanism by which individual participants were } \\
\text { included in clusters for the purposes of the trial } \\
\text { (such as complete enumeration, random } \\
\text { sampling) }\end{array}$ & Methods / study design and participants \\
\hline $10 c$ & $\begin{array}{l}\text { From whom consent was sought (representatives of } \\
\text { the cluster, or individual cluster members, or both) } \\
\text { and whether consent was sought before or after } \\
\text { randomization }\end{array}$ & Methods / ethics statement \\
\hline \multicolumn{3}{|c|}{ Blinding } \\
\hline $11 a$ & $\begin{array}{l}\text { If done, who was blinded after assignment to } \\
\text { interventions (for example, participants, care } \\
\text { providers, those assessing outcomes) and } \\
\text { how }\end{array}$ & Methods / randomization and masking \\
\hline $11 b$ & $\begin{array}{l}\text { If relevant, description of the similarity of } \\
\text { interventions }\end{array}$ & Methods / randomization and masking \\
\hline \multicolumn{3}{|c|}{ Statistical Methods } \\
\hline $12 a$ & $\begin{array}{l}\text { Statistical methods used to compare groups for } \\
\text { primary and secondary outcomes; How } \\
\text { clustering was taken intoaccount }\end{array}$ & Methods / statistical analysis \\
\hline $12 b$ & $\begin{array}{l}\text { Methods for additional analyses, such as } \\
\text { subgroup analyses and adjusted analyses }\end{array}$ & $\begin{array}{l}\text { Methods / longitudinal rate } \\
\text { estimates } \\
\text { Methods / subgroup analyses }\end{array}$ \\
\hline \multicolumn{3}{|c|}{ Results } \\
\hline \multicolumn{3}{|c|}{ Participant Flow } \\
\hline $13 a$ & $\begin{array}{l}\text { For each group, the numbers of } \\
\text { participants/clusters who were randomly } \\
\text { assigned, received intended treatment, and were } \\
\text { analyzed for the primary outcome }\end{array}$ & $\begin{array}{l}\text { Results / study population and setting } \\
\text { Figure } 1\end{array}$ \\
\hline $13 b$ & $\begin{array}{l}\text { For each group, losses and exclusions after } \\
\text { randomization, together with reasons, for } \\
\text { both clusters and individual cluster members }\end{array}$ & Figure 1 \\
\hline \multicolumn{3}{|c|}{ Recruitment } \\
\hline $14 a$ & $\begin{array}{l}\text { Dates defining the periods of recruitment } \\
\text { and follow-up }\end{array}$ & $\begin{array}{l}\text { Results / study population and setting } \\
\text { SI Figure } 3\end{array}$ \\
\hline $14 b$ & Why the trial ended or was stopped & $N / A$ \\
\hline
\end{tabular}


medRxiv preprint doi: https://doi.org/10.1101/2021.04.23.21255957; this version posted April 26, 2021. The copyright holder for this preprint

(which was not certified by peer review) is the author/funder, who has granted medRxiv a license to display the preprint in perpetuity.

This article is a US Government work. It is not subject to copyright under 17 USC 105 and is also made available for use under a CCO license.

\begin{tabular}{|c|c|c|}
\hline Item & Description & Reported in Section \\
\hline \multicolumn{3}{|c|}{ Baseline Data } \\
\hline 15 & $\begin{array}{l}\text { A table showing baseline demographic and clinical } \\
\text { characteristics for each group; Baseline } \\
\text { characteristics for the individual and cluster levels } \\
\text { as applicable for each group }\end{array}$ & Table 1 \\
\hline \multicolumn{3}{|c|}{ Numbers Analysed } \\
\hline 16 & $\begin{array}{l}\text { For each group, number of participants/clusters } \\
\text { (denominator) included in each analysis and } \\
\text { whether the analysis was by the original } \\
\text { assigned groups }\end{array}$ & Figure 1 \\
\hline \multicolumn{3}{|c|}{ Outcomes and Estimation } \\
\hline $17 a$ & $\begin{array}{l}\text { For each primary and secondary outcome, results } \\
\text { for each group, and the estimated effect size and } \\
\text { its precision (such as } 95 \% \text { confidence interval); } \\
\text { Results at the individual and cluster levels as } \\
\text { applicable and a coefficient of intracluster } \\
\text { correlation (ICC ork) for each primary outcome }\end{array}$ & $\begin{array}{l}\text { Figures 2, } 3 \\
\text { SI Figures 5, 6, 7, } 8\end{array}$ \\
\hline $17 b$ & $\begin{array}{l}\text { For binary outcome, presentation of both } \\
\text { absolute and relative effect sizes is } \\
\text { recommended }\end{array}$ & Figures 2, 3 \\
\hline \multicolumn{3}{|c|}{ Ancillary Analyses } \\
\hline 18 & $\begin{array}{l}\text { Results of any other analyses performed, including } \\
\text { subgroup analyses and adjusted analyses, } \\
\text { distinguishing pre-specified from exploratory }\end{array}$ & $\begin{array}{l}\text { SI Figures 9, } 10 \\
\text { SI Table 1, } 2\end{array}$ \\
\hline \multicolumn{3}{|c|}{ Harms } \\
\hline 19 & $\begin{array}{l}\text { All important harms or unintended effects in each } \\
\text { group }\end{array}$ & N/A \\
\hline \multicolumn{3}{|c|}{ Discussion } \\
\hline \multicolumn{3}{|c|}{ Limitations } \\
\hline 20 & $\begin{array}{l}\text { Trial limitations, addressing sources of potential } \\
\text { bias, imprecision and, if relevant, multiplicity of } \\
\text { analyses }\end{array}$ & Discussion, paragraph 4 \\
\hline \multicolumn{3}{|c|}{ Generalisability } \\
\hline 21 & $\begin{array}{l}\text { Generalisability (external validity, applicability) of } \\
\text { the trial findings; Generalisability to clusters and/or } \\
\text { individual participants (as relevant) }\end{array}$ & Discussion, paragraph 4 \\
\hline
\end{tabular}


medRxiv preprint doi: https://doi.org/10.1101/2021.04.23.21255957; this version posted April 26, 2021. The copyright holder for this preprint

(which was not certified by peer review) is the author/funder, who has granted medRxiv a license to display the preprint in perpetuity.

This article is a US Government work. It is not subject to copyright under 17 USC 105 and is also made available for use under a CCO license.

\begin{tabular}{|c|c|c|}
\hline Item & Description & Reported in Section \\
\hline \multicolumn{3}{|c|}{ Interpretation } \\
\hline 22 & $\begin{array}{l}\text { Interpretation consistent with results, balancing } \\
\text { benefits and harms, and considering other } \\
\text { relevant evidence }\end{array}$ & Discussion, paragraphs $1,2,3$ \\
\hline \multicolumn{3}{|c|}{ Other Information } \\
\hline \multicolumn{3}{|c|}{ Registration } \\
\hline 23 & Registration number and name of trial registry & $\begin{array}{l}\text { Methods / study design and participants } \\
\text { Trial: clinicaltrials.gov: } \underline{\text { NCT02048007 }} \\
\text { Analysis plan: osf.io: https://osf.io/d9s4t }\end{array}$ \\
\hline \multicolumn{3}{|c|}{ Protocol } \\
\hline 24 & $\begin{array}{l}\text { Where the full trial protocol can be accessed, } \\
\text { if available }\end{array}$ & SI Protocol 1 \\
\hline \multicolumn{3}{|c|}{ Funding } \\
\hline 25 & $\begin{array}{l}\text { Sources of funding and other support (such as } \\
\text { supply of drugs), role of funders }\end{array}$ & Acknowledgements \\
\hline
\end{tabular}

